\title{
LA CESACIÓN UNILATERAL DEL CONTRATO DE OBRA PREVISTA EN EL ART. 1999 INC. $2^{\circ}$ DEL CÓDIGO CIVIL
}

\section{THE UNILATERAL CESSATION OF THE CONSTRUCTION CONTRACT STIPULATED ON ART. $19992^{\circ}$ INC. OF THE CIVIL CODE}

Andrés Erbetta Mattig*

\section{REsUMeN}

El art. 1999 inc. $2^{\circ}$ del Código Civil faculta al mandante de la obra para hacerla cesar anticipadamente, reembolsando al artífice los gastos y dándole la utilidad que le habría reportado de haberse ejecutado completamente. No obstante, tratarse de una disposición con orígenes en Robert Pothier y el Código Civil francés, presente en la mayoría de los códigos herederos de esta tradición, no abundan en nuestro país comentarios doctrinarios ni jurisprudencia reciente que permita ilustrar el supuesto de hecho y la naturaleza de sus efectos.

Palabras claves: Cesación de la obra, reembolso y pago de la utilidad, indemnización de perjuicios.

* Abogado. Licenciado en Ciencias Jurídicas por la Universidad Diego Portales. Alumno regular del programa de Doctorado en Derecho de la Universidad de los Andes (Chile). Dirección postal: Monseñor Álvaro del Portillo 12.455, Las Condes. Correo electrónico: aerbettamattig@gmail.com. Artículo recibido el 18 de marzo de 2016 y aceptado para su publicación el 16 de septiembre de 2016.

Este trabajo forma parte del proyecto FONDECYT regular $N^{\circ} 1150634$ : "Revisión crítica y homologación de modelos estandarizados internacionales de contratos de construcción en el derecho chileno público y privado", dirigido por la profesora Dra. María Sara Rodríguez Pinto.

Agradecemos las sugerencias y comentarios de los profesores Cristián Banfi del Río y Jorge Baraona González, así como de los árbitros anónimos que revisaron la versión preliminar de este trabajo. 


\begin{abstract}
The 1999 article (sub. 2) from the Civil Code allows the owner of the project to have an early finish of the work making a total refund to the builder of the earnings and costs of completing the work. This rule has its origin in Robert Pothier and in the French Civil Code, and it is present in the main codes that are heirs of this tradition. In Chile there are not developments or juridical comments that endorse these principles and the nature of its effects.
\end{abstract}

Key words: Early finish of the work, refund of the costs and earnings, damage compensation.

\title{
I. INTRODUCCIÓN
}

El art. 1999 del $C C^{1}$ señala:

"Habrá lugar a reclamación de perjuicios, según las reglas generales de los contratos, siempre que por una o por otra parte no se haya ejecutado lo convenido, o se haya retardado su ejecución. Por consiguiente, el que encargó la obra, aun en el caso de haberse estipulado un precio único y total por ella, podrá hacerla cesar, reembolsando al artífice todos los costos, y dándole lo que valga el trabajo hecho y lo que hubiere podido ganar en la obra”.

Esta disposición se ubica en el $\S 8$ del título xxvi del libro IV, relativo a los contratos para la confección de una obra material, y contempla dos reglas. La primera, permite a la parte insatisfecha resarcirse de los perjuicios causados por el incumplimiento contractual, según "las reglas generales de los contratos" (inc. $1^{\circ}$ ). La segunda, establece que el que encargó la obra puede "hacerla cesar", debiendo reembolsar al artífice los costos y el trabajo hecho, junto con el pago de la utilidad estipulada en el contrato (inc. $2^{\circ}$ ). Es la regla que denominamos de "cesación unilateral del contrato de obra" o simplemente de "cesación" 2 . al $C C$.

${ }^{1}$ En adelante, salvo que se indique otra cosa, todos los artículos citados corresponden

${ }^{2}$ Como señala Rodríguez (1991), pp. 53-54, tanto la doctrina como la legislación comparada emplean un sinnúmero de denominaciones para tratar de la misma regla como: desistir, denunciar, disolver, renunciar, rescindir y revocar. En el Derecho español, parte de la doctrina ha visto en el art. 1594 del $C C$ esp. un derecho de desistimiento, por los términos empleados en dicha disposición. Para Morales Moreno (2010), p. 59, sin embargo, no se trata 
La cesación no ha sido objeto de gran interés, por lo menos en nuestro país. Además, salvo fallos aislados -en algunos casos bastante antiguos-, no existe un caudal jurisprudencial que permita ilustrar con claridad su sentido y alcance. Creemos, sin embargo, que la particular fisonomía de esta figura impone hacernos cargo de ella.

Un primer aspecto de relevancia es que el mandante, actuando en forma unilateral y sin el concurso del artífice, puede terminar anticipadamente la obra empezada, lo que parece sugerir una excepción al principio del efecto obligatorio de los contratos previsto en el art. 1545 del $C C$. En este contexto, obraría lícitamente en virtud de una facultad expresa prevista en la ley. No obstante, esta interpretación podría chocar con la conjunción "por consiguiente" empleada al comienzo del art. 1999 inc. $2^{\circ}$ del $C C$, con arreglo a la cual el desistimiento del contrato sería una derivación de la regla contenida en el inc. $1^{\circ}$, que, como dijimos, refiere al remedio indemnizatorio. Pensada de este modo, no estaríamos frente a una excepción al efecto obligatorio de los contratos, sino ante un incumplimiento contractual, deducción abonada por las consecuencias previstas en el art. 1999 inc. $2^{\circ}$ del CC in fine. Veremos, con todo, que estas no son las únicas interpretaciones posibles. En efecto, más allá de su configuración unilateral, no debe perderse de vista que su ejercicio importa, al fin de cuentas, el pago de la utilidad estipulada en favor del artífice. De acuerdo con lo anterior, el encuadramiento de la cesación como un supuesto de incumplimiento contractual también resulta debatible.

En segundo lugar, esta disposición no parece asignar al mandante la carga de justificar la interrupción de la obra, ni menos que ella opere bajo una modalidad determinada, lo que podría llevarnos a concluir que su ejercicio es discrecional. Sin embargo, sabido es que en nuestro ordenamiento la buena fe constituye un principio que impregna a todas las fases de la contratación, con lo cual esa máxima podría admitir examen. En concreto, la interrogante que surge es si debemos contentarnos con aceptar el recurso caprichoso de la cesación o, por el contrario, si es posible sujetarla a determinadas reglas o límites.

$\mathrm{Al}$ alero de lo expuesto, este trabajo se abocará al estudio del art. 1999 inc. $2^{\circ}$ del $C C$, dividiéndolo en cinco apartados:

- En el primero (II) se analizarán los antecedentes históricos del art. $1999 \mathrm{del} C C$, pesquisa que se justifica por sus aportes a la configuración dogmática de la cesación.

- En el segundo (III) nos referiremos a la inserción del art. 1999 en el $C C$ y a los efectos de la cesación unilateral de la obra, a objeto de cotejarla con sus precedentes históricos.

de un verdadero derecho a desistir, sino, más bien, de un derecho a paralizar la ejecución in natura del contrato (en los términos pactados) y sustituirla por el remedio de la indemnización del daño. Por nuestra parte, hemos optado por mantener la nomenclatura empleada en la ley. 
- En el siguiente (IV) dedicaremos algunos comentarios a la regulación de los riesgos contractuales en la confección de obra material, con miras a la determinación de sus presupuestos fácticos.

- En el cuarto (v. nos referiremos a los supuestos de hecho de la cesación y a las limitaciones de esta figura.

- Finalmente (vi), el trabajo terminará con las conclusiones a las cuales podamos arribar.

\section{ANTECEDENTES HistóRICOS DEL ART. 1999 DEL $C C$}

La fuente inmediata del art. 1999 del $C C$ se encuentra en el art. 1794 del $C C$ fra del año $1804^{3}$, como se desprende de la nota que Andrés Bello puso en el art. 2190 del Proyecto de $1853^{4}$. Al decir de la doctrina ${ }^{5}$, la generalidad de las legislaciones herederas del $C C$ fra conceden al mandante de la obra el derecho a denunciarla, indemnizando al contratista, lo que demuestra su influencia universal. En efecto, disposiciones similares se encuentran en los códigos de Alemania $^{6}$, España $^{7}$, Italia $^{8}$, Portugal $^{9}$,

${ }^{3}$ El art. 1794 del $C C$ fra señala: "El dueño puede desistir, por su sola voluntad, de la contrata a precio alzado aunque haya comenzado la obra, indemnizando al contratista todos sus gastos, de todos sus trabajos y de todo lo que habría podido ganar con esa contrata”. La traducción es libre del autor.

${ }^{4}$ Bello (1888), p. 525.

${ }^{5}$ Por todos Rezzonico (1959), p. 815 y Castan (1988), p. 518.

${ }^{6} \S 649$ del $B G B$ : "El comitente puede denunciar el contrato en cualquier momento hasta la finalización de la obra. Si el comitente denuncia, el contratista está facultado para exigir la remuneración pactada; sin embargo, debe dejarse deducir lo que ahorra a consecuencia de la extinción del contrato o lo que obtiene por otro empleo de su fuerza de trabajo o que maliciosamente ha dejado de obtener". La traducción la hemos tomado de LAMARCa (2013), p. 197.

${ }^{7}$ Art. 1594 del $C C$ esp: "El dueño puede desistir, por su sola voluntad, de la construcción de la obra aunque se haya empezado, indemnizando al contratista de todos sus gastos, trabajo y utilidad que pudiera obtener de ella".

${ }^{8}$ Art. 1671 del $C C$ ita de 1942: "El comitente puede separarse del contrato, aun cuando se haya iniciado la ejecución de la obra o la prestación del servicio, siempre que mantenga indemne al contratista de los gastos soportados, de los trabajos realizados y de la falta de ganancia”. La traducción es de Sentis Melendo (1954), p. 309.

En la misma línea, se encuentra el art. 1641 del $C C$ ita de 1865: "El dueño puede, por sola su voluntad, rescindir el contrato de destajo aun cuando se hubiese empezado ya el trabajo, indemnizando al contratista los gastos de todos los trabajos y de todo lo que hubiera podido ganar en semejante empresa". La traducción es de AGUILERA y Velasco (1881), p. 231.

${ }^{9}$ Art. 1229 del $C C$ por: "Desistência do dono da obra. O dono da obra pode desistir da empreitada a todo o tempo, ainda que tenha sido iniciada a sua execução contanto que indemnize o empreiteiro dos seus gastos e trabalho e do proveito que poderia tirar da obra". 
Argentina $^{10}$, Bolivia $^{11}$, Colombia $^{12}$, Ecuador $^{13}$, México $^{14}$, Paraguay $^{15}$, Perú $^{16}$, Uruguay $^{17}$, Venezuela ${ }^{18}$, por nombrar algunos. A su turno, todo indica que

${ }^{10}$ Art. 1261 del $C C$ ar de 2015: "Desistimiento unilateral. El comitente puede desistir del contrato por su sola voluntad, aunque la ejecución haya comenzado; pero debe indemnizar al prestador todos los gastos y trabajos realizados y la utilidad que hubiera podido obtener. El juez puede reducir equitativamente la utilidad si la aplicación estricta de la norma conduce a una notoria injusticia".

El antiguo art. 1638 del $C C$ ar, vigente hasta el año 2015, disponía: "El dueño de la obra, puede desistir de la ejecución de ella, aunque se haya empezado, indemnizando al locador todos sus gastos, trabajo y utilidad que pudiera obtener por el contrato. Empero, los jueces podrán reducir equitativamente la utilidad a reconocer si la aplicación estricta de la norma condujera a una notoria injusticia".

${ }^{11}$ Art. 746 del $C C$ bo: "(Rescisión del contrato). I. El comitente puede rescindir unilateralmente el contrato, aún cuando se haya iniciado la obra, resarciendo al contratista por los gastos y trabajos realizados y la falta de ganancia. II. El contratista puede también rescindir unilateralmente el contrato por justo motivo, con derecho a ser reembolsado por los gastos y a la retribución por la obra realizada, y siempre que no cause perjuicio al comitente".

12 Art. 2056 del $C C$ co: "Habrá lugar a reclamación de perjuicios, según las reglas generales de los contratos, siempre que por una o por otra parte no se haya ejecutado lo convenido, o se haya retardado su ejecución. Por consiguiente, el que encargó la obra, aun en el caso de haberse estipulado un precio único y total por ella, podrá hacerla cesar, reembolsando al artífice todos los costos, y dándole lo que valga el trabajo hecho, y lo que hubiere podido ganar en la obra".

${ }^{13}$ Art. 1933 del $C C$ ec: "Habrá lugar a reclamación de perjuicios, según las reglas generales de los contratos, siempre que por una o por otra parte no se haya ejecutado lo convenido, o se haya retardado su ejecución. Por consiguiente, el que encargó la obra, aún en el caso de haberse estipulado un precio único y total por ella, podrá hacerla cesar, pagando al artífice todos los costos, y dándole lo que valga el trabajo hecho, y lo que hubiera podido ganar en la obra".

${ }^{14}$ Art. 2635 del $C C$ me: "El dueño de una obra ajustada por un precio fijo, puede desistir de la empresa comenzada, con tal que indemnice al empresario de todos los gastos y trabajos y de la utilidad que pudiera haber sacado de la obra".

${ }^{15}$ Art. 862 del $C C$ pa: "El que encomienda la obra puede desistir de su ejecución aún después de comenzada, indemnizando a la otra parte todos sus gastos, trabajo y utilidad que hubiere podido obtener por el contrato. Sin embargo, los jueces podrán reducir equitativamente la indemnización por la utilidad no percibida, si la aplicación estricta de la norma condujere a una notoria injusticia. Para este efecto tomarán en cuenta principalmente lo que el constructor ganó o pudo ganar al liberarse de su obligación".

${ }^{16}$ Art. 1786 del $C C$ pe: "Facultad del comitente. El comitente puede separarse del contrato, aun cuando se haya iniciado la ejecución de la obra, indemnizando al contratista por los trabajos realizados, los gastos soportados, los materiales preparados y lo que hubiera podido ganar si la obra hubiera sido concluida".

${ }^{17}$ Art. 1847 del $C C$ ur: "El que encarga una obra para la que el obrero debe poner los materiales, puede a su arbitrio rescindir el contrato, aunque la obra ya esté empezada a ejecutar, indemnizando al obrero de todos los gastos y trabajos y de todo lo que hubiera podido ganar en la misma obra".

${ }^{18}$ Art. 1639 del $C C$ ve: "El dueño puede desistir por su sola voluntad de la construcción de la obra, aunque se haya empezado, indemnizando al contratista de todos sus gastos, de su trabajo y de la utilidad que hubiese podido obtener de ella”. 
la legislación francesa se inspiró en el trabajo de Robert Pothier sobre el contrato de locación ${ }^{19}$. Examinaremos ambas aportaciones con el objeto de indagar su influjo en la disposición contenida en el $C C$.

\section{La obra de Robert Pothier}

En su célebre Tratado de la locación conducción, distingue la locación conducción de obras y de cosas. En esta última, el objeto y materia "es el goce de una cosa concedido por cierto precio", mientras que en la de obras el objeto y la materia "es una obra que se encarga hacer" 20 . Estos contratos, sin embargo, "convienen en muchas circunstancias". Ambos, sostiene, son "consensuales, sinalagmáticos y conmutativos"21, 22.

En el capítulo IV de la parte séptima de su libro, se pregunta (§ 2) si el contrato de locación conducción de obras puede disolverse por la voluntad de una sola de las partes ${ }^{23}$. En lo que toca al locador (mandante), afirma que este "siempre que crea conveniente el que no se haga la obra que había encargado, puede separarse del contrato, advirtiéndoselo al conductor é indemnizándole"24 (l'indemnifant $\ell^{5}$ ). Pero más adelante niega esta prerrogativa para el conductor (artífice), quien, después de concluido el contrato, "no podrá ya excusarse de darle cumplimiento" 26,27 . En efecto, si este retarda el cumplimiento

“puede el locador compelerle á ello, y el tribunal dispondrá que no empezando la obra en el tiempo que se le prescriba, quedará

${ }^{19}$ Planiol y Ripert (1991), p. 399 y Huet (1996), p. 1307. Lo mismo sostiene Rodríguez (1991), pp. 314-315, en relación con el art. 1594 del $C C$ esp.

${ }^{20}$ Pothier (1841), p. 176.

${ }^{21}$ Ibid.

${ }^{22}$ Cabe agregar que, en sus orígenes romanos, la locatio conductio se estructura como un contrato consensual, junto a la compraventa, la sociedad y el mandato. Con ella se designaba una serie de relaciones jurídicas que con posterioridad constituyeron contratos autónomos, como lo son el arrendamiento de cosas, de obras y de servicios (locatio conductio rei, locatio conductio operis y locatio conductio operum, según la tardía configuración efectuada por la pandectística del siglo XIX). Esta tripartición, empero, no aparece en los comentarios de los glosadores y posglosadores. Estos se limitan a poner de relieve que el objeto de la locatio conductio puede consistir en la cesión del uso de una cosa o en la cesión de trabajo (obras o servicios). Posteriormente, Jean Domat distingue tres tipos de arrendamiento: el simple arrendamiento (de cosas), el de fincas rústicas y los ajustes y otros arrendamientos de trabajo y de industria. En este sentido, Solé (1996), pp. 3-37.

${ }^{23}$ Pothier (1841), pp. 198-200.

${ }^{24}$ Op. cit., p. 198.

${ }^{25}$ Pothier (1764), p. 392.

${ }^{26}$ Pothier (1841), p. 200.

${ }^{27} \mathrm{Al}$ respecto, un sector de la doctrina ha deslizado una crítica con relación a la exclusividad de la cesación unilateral en favor del mandante. En este sentido podemos mencionar a HEDEMANN (1958), p. 423, quien, comentando el $\S 649$ el BGB, la estima una “evidente parcialidad" a favor del dueño de la obra. 
el locador autorizado para ajustarse con otro empresario, á fin de que haga la obra de cuenta y riesgo de dicho conductor, á quien se citará para que asista a la celebración del nuevo contrato" 28 .

Asimismo, agrega que la cesación de la obra no precisa que el mandante justifique su ejercicio. Este se apoya en

"razones muy poderosas para dejar de edificar, razones de que no puede precisárseme a dar cuenta: pueden haber acontecido pérdidas de consideración en mis bienes, que me pongan en la imposibilidad de hacer el gasto que tenía proyectado" 29 .

Con ello, bosqueja una facultad ad nutum $^{30}$, que no exige la prueba de una justa causa. Cesada la obra, el artífice no podrá oponerse a la determinación del mandante, ni pretender aquel el pago por entero del precio convenido, "ofreciéndose por su parte á cumplir su obligación" ${ }^{1}$. De este modo, entiende que concurre una figura extintiva de la relación contractual de obras, que, una vez comunicada, obliga al artífice a suspender la ejecución "desde aquél mismo día" 32 .

Ahora bien, para que la cesación produzca efectos, el mandante debe "advirtiéndoselo al conductor e indemnizándole". Esta indemnización comprende los gastos en que hubiera incurrido el artífice,

“como si antes de declararle mi resolución hubiese hecho algún acopio de materiales, que después tuviese que volver á vender con pérdida; si hubiese ya alquilado trabajadores que han de serle inútiles"33, y "el precio de lo hecho, regulado á proporción del precio convenido" 34 . Pero la indemnización que debe pagar el mandante no se limita únicamente a los costos de la obra y la utilidad proyectada. Alcanza, también, a "la ganancia, que hubiera podido hacer con otras contratas, que le ha impedido verificar aquella cuya disolución se pide" ${ }^{35}$. En otras palabras, Robert Pothier considera que la indemnización, además de poner al artífice en la misma posición en que se hubiera encontrado con el cumplimiento en naturaleza del contrato, incluye todas las ganancias que dejó de ganar con él, acumu-

\footnotetext{
${ }^{28}$ Pothier (1841), p. 200.

${ }^{29}$ Op. cit., pp. 198-200.

${ }^{30}$ KLEIN (1997), p. 34.

${ }^{31}$ Pothier (1841), p. 198.

${ }^{32}$ Op. cit., p. 199.

${ }^{33}$ Ibid.

${ }^{34}$ Ibid.

${ }^{35}$ Ibid.
} 
lando al interés positivo un interés negativo ${ }^{36}$, como lo es la pérdida de la oportuni$d a d^{37}$.

No obstante, en el contexto de las normas herederas de la tradición de Robert Pothier y del $C C$ fra, la acumulación de estos intereses ha sido criticada como opción legislativa, bajo la imputación de encubrir un enriquecimiento injustificado ${ }^{38}$, provocado por el aumento patrimonial en su

${ }^{36}$ Parece pertinente citar la opinión de Fischer (1928), pp. 97-98, quien entiende que la indemnización del interés contractual positivo "no requiere el desistimiento del negocio válido; antes al contrario, presupone su ejecución, aunque en vez del cumplimiento efectivo -el cual resulta imposible o carece del interés para el reclamante- éste exija otro objeto, subsidiario a la prestación principal: la demanda tiene su base en el contrato o negocio jurídico, válido y perfecto. Interés contractual negativo llámase, por el contrario, aquel que se irroga a quien confía en la validez de un negocio jurídico que luego resulta nulo, bien por vicio original o por causas posteriores". Véanse también Fuller y PERdue (1957), p. 10; Contardo (2011) p. 87 y PALAZÓn (2014), pp. 190-193.

${ }^{37}$ Como apuntan Ríos Erazo y Silva GoÑi (2014), p. 262, la pérdida de la oportunidad constituye "la frustración actual de una probabilidad de alcanzar una situación patrimonial o extrapatrimonial más beneficiosa, o de evitar un empeoramiento de la situación patrimonial o extrapatrimonial presente".

${ }^{38}$ Discusión que se extiende al pago de las partidas comprendidas normalmente dentro de los efectos de la cesación de la obra.

16 Así, por ejemplo, comentando el art. 1594 del $C C$ esp, Vaquero (2005), pp. 471-472, señala: "Lo que puede destacarse, en cualquier caso, es la improcedencia de pedir acumuladamente el interés de confianza y el interés de cumplimiento al resultar contradictorio y abusivo; contradictorio, porque se estarán reclamando las ventajas de la resolución y la indemnidad por los costes y sacrificios patrimoniales afrontados para ejecutar el contrato, abusivo, porque daría lugar al enriquecimiento del resolvente a costa del incumplidor ya que la prestación resarcitoria no debe colocar al perjudicado en una situación mejor que aquella en la que se encontraría en ausencia del evento lesivo". En su opinión, el art. $1594 \mathrm{del} C C$ esp precisamente adolece de esta contradicción y abuso, al contemplar en favor del artífice de la obra partidas reconducibles al interés negativo ("gastos" y "trabajo") y al positivo ("utilidad que pudiera obtener de ella"), porque "resulta indudable que, el prestador, como consecuencia de la extinción del contrato de servicios, se encuentra en posición de ocupar en forma alternativa sus recursos pudiendo conseguir, en ocasiones, más que su indemnidad, un injustificado enriquecimiento".

No obstante, esta postura no es unánime. En este sentido, LAMARCA (2001), pp. 196197, entiende que la cesación de la obra del art. 1594 del $C C$ esp protege solo el interés contractual positivo del artífice.

En el Derecho estadounidense, Fuller y Perdue (1957), pp. 36-41, plantean que en el mismo supuesto -mandante que quebranta o repudia la obra antes de que haya tenido lugar el pleno cumplimiento- es posible clasificar la acción del artífice "como fundada sólo en el interés dirigido a la prestación esperada, o en una combinación de este interés y el de confianza". En efecto, "si un contratista de obras ha terminado la mitad de la estructura cuando el propietario desiste del contrato, el contratista puede incluir en su reclamación dos clases de daños: 1) los gastos en que efectivamente ha incurrido con ocasión del cumplimiento o al prepararse a cumplir, y 2) el provecho que hubiese derivado de la ejecución de todo el contrato", con lo cual pareciera que nos encontramos ante una combinación de los intereses 
proyección sobre el activo del artífice, que se concreta en un incremento que se incorpora a su patrimonio, sin que exista una efectiva contraprestación ${ }^{39}$. En todo caso, como veremos a continuación, esta vía dista del camino adoptado finalmente por el Código napoleónico.

\section{El art. 1794 del CC francés}

La sistemática del $C C$ fra en materia de arrendamiento sigue esencialmente a Robert Pothier y en menor medida a la doctrina de Jean Domat ${ }^{40}$. Distingue, así, el contrato de arrendamiento de cosas (incluyendo el de casas y bienes rústicos, arrendamientos urbanos y fincas rústicas), de obra e industria (que, a su vez, abarca el de criados y trabajadores asalariados, transportes por tierra y agua, y las contratas), y el contrato de aparcería. El art. 1794 del $C C$ fra se ubica dentro de la sección destinada a las contratas (des devis et des marchés ${ }^{41}$.

Aunque su cesación recoge algunos elementos de la obra de Robert Pothier, se aleja considerablemente de otros. Ambos coinciden en el carácter ad nutum y la radicación exclusiva de la facultad en el mandante, características que, en todo caso, fueron objeto de un intenso intercambio doctrinal, provocado por la parquedad del precepto y la necesidad de delimitar sus contornos para resolver problemas prácticos.

Así, por ejemplo, en cuanto al carácter ad nutum, algunos autores, como Ambroise Colin y Henri Capitant, sostuvieron que constituía un dispositivo para enfrentar las alteraciones sobrevenidas que puedan impactar en el interés del mandante incauto.

"Sucede a menudo que el que encarga un trabajo de esta índole obra imprudentemente -afirman-, ya que, dado el tiempo que se invierte en su ejecución, puede suceder que al llegar el momento de concluirlo hayan quedado sus recursos tan disminuidos que no le permitan pagarlo" 42 .

de confianza y dirigido a la prestación esperada. Pero "cuando el demandante ha empezado a cumplir un contrato ventajoso o se ha preparado para hacerlo antes del quebrantamiento por parte del demandado, puede afirmarse sin temor a desfigurar la realidad que lo esperado por el demandante es verdaderamente doble y que incluye: 1) el reembolso de lo que ya ha ejecutado, y 2) un provecho adicional. Podemos hablar en este caso del interés total que deriva de la prestación (gross expectation interest). Con este concepto, la acción del contratista en el caso supuesto aparecerá fundada por completo en el interés dirigido a la prestación esperada".

${ }^{39}$ En este sentido, Orozco (2015), p. 85.

${ }^{40}$ SOLÉ (1996), p. 39. Véase supra n. 22.

${ }^{41} \mathrm{El}$ art. 1787 del $C C$ fra, que encabeza dicha sección, señala: "Cuando alguien se encargue de hacer una obra, puede acordarse de que ponga solamente su trabajo o industria, o que suministre también el material”. Traducción libre del autor.

${ }^{42}$ Colin y Capitant (1925), p. 359. 
Otros, en cambio, destacan que la figura es absolutamente natural y conforme a los usos, considerando que su ejercicio no solo obliga a pagar lo que se ha hecho sino el beneficio que el artífice esperaba obtener ${ }^{43,44}$.

Por su lado, la unilateralidad de ejercicio en favor del mandante indujo a un sector de la doctrina francesa a estimar que la cesación constituye una excepción al principio del efecto obligatorio de los contratos ${ }^{45,46}$, limitando su ámbito de aplicación ${ }^{47}$. No obstante, esta interpretación restrictiva, que liga el efecto obligatorio del contrato con su estructura externa ${ }^{48}$, ha contado desde antiguo con notables excepciones. Es el caso de Théophile Huc, quien enlaza la irrevocabilidad del contrato con la satisfacción del interés del acreedor ${ }^{49,50}$.

${ }^{43}$ Planiol y Ripert (1991), p. 399.

${ }^{44}$ En la misma línea se ubica la discusión sobre el tipo contractual en el que resultaba admisible la cesación. Como se desprende de la lectura del art. 1794 del $C C$ fra, este pareciera incardinarla solo en relación con los contratos a suma alzada de construcción de edificaciones, como lo entendieron Colin y Capitant (1925), p. 360. Así interpretada por la jurisprudencia francesa, la figura vio limitado su ámbito de aplicación durante casi todo el siglo XIX. Actualmente, se entiende que la cesación tiene un alcance general y, por ende, aplicable a todo contrato de obra y trabajos efectuados a precio alzado. En este sentido, véase Planiol y Ripert (1991), p. 399.

Cabe hacer presente que el art. 1999 del $C C$, por su parte, no presenta esta dificultad interpretativa, al disponer que opera "aun en el caso de haberse estipulado un precio único y total por ella", lo que la extiende, a contrario sensu, a todo tipo de contratas.

${ }^{45}$ En este sentido, Colin y Capitant (1925), p. 359. También Baudry-Lacantinerie (1925), p. 469.

${ }^{46}$ Previsto en el actual art. 1193 del $C C$ fra, conforme a la ordenanza No 2016-131, vigente desde el 1 de octubre de 2016.

${ }^{47}$ Planiol y Ripert (1991), p. 399.

${ }^{48}$ Siguiendo a Alonso Pérez (1967), pp. 10-11, entendemos por esta el dato exterior, cuantitativo, del número y proveniencia de las declaraciones de voluntad, de los sujetos que intervienen en el acto de autonomía privada. Por contraposición, un punto de vista interno alude a la mecánica intrínseca y dinámica del contrato, vinculado al cumplimiento de las prestaciones recíprocas.

${ }^{49}$ Huc (1897), pp. 598-599: "así, pues, si el art. 1794, C.C. francés, no existiera, un pocero, por ejemplo, que se hubiera encargado de cavar un pozo tendría el derecho adquirido de cavarlo en contra de la voluntad del propietario, que ya hubiera encontrado el agua que necesitaba. Los contratos tienen por base la utilidad de una de las partes o de ambas, como establece el art. 1137; son irrevocables en cuanto el emolumento que debe resultarle no se le puede privar al que debe aprovecharlo. Para el obrero o empresario, dicho emolumento consiste en el beneficio esperado; luego, si se le asegura este beneficio, no tiene otra cosa que reclamar. Para el dueño, el emolumento consiste en la obra misma que debe hacerse". Traducción adaptada de Rezzonico (1959), p. 817. En un sentido similar, véase KLEIN (1997), p. 89.

${ }^{50}$ La unilateralidad de la regla también ha servido a algunos para discurrir sobre los antecedentes remotos de la cesación. En efecto, parte de la doctrina que ha analizado el art. 1594 del $C C$ esp, tributario también del art. 1794 del $C C$ fra, ha sostenido que la fuente 
En cuanto a las divergencias, la más relevante se refiere a los efectos que produce la cesación. Como se expuso, en el Tratado de Robert Pothier la indemnización permite anexar al interés positivo (valor de la prestación) la pérdida de la oportunidad, acumulación que recibió fuertes críticas. En cambio, el $C C$ fra limita la denominada indemnización (dédommageant) del artífice a "todos sus gastos, todos sus trabajos y toda utilidad que pudiera haber obtenido en esta obra" ${ }^{51}$. La doctrina ha entendido que se comprenden en los gastos aquella parte del trabajo ya efectuado, así como las compras de materiales o de útiles que haya podido hacer, y por ganancia lo que él hubiera podido obtener si hubiese terminado la obra ${ }^{52}$. La indemnización del lucro que habría reportado para la conclusión de otras obras no aparece en el art. 1794 del $C C$ Fra, por lo menos como un efecto inmediato de la cesación.

De acuerdo con lo anterior, resulta pertinente preguntarnos si el art. 1794 del $C C$ fra produce consecuencias indemnizatorias automáticas. Un sector de la doctrina -a la cual adherimos- sostiene que la indemnización persigue la reparación de los daños que exceden el valor de prestación, desconociéndole una función restitutoria o de reintegración por equivalente del crédito lesionado, que a la vez es sustitutiva o subrogatoria de la prestación incumplida ${ }^{53}$. Para esta comprensión, los perjuicios constituyen un complemento del acreedor a ser resarcido cada vez que la infracción de la obligación le suponga un daño, conforme a las normas de imputación y extensión que contemple el respectivo ordenamiento ${ }^{54}$. Los daños, entonces, son complementarios a la prestación misma y afectan otros intereses del acreedor.

mediata de la obra de Robert Pothier, en la cual se inspiró a su vez el Code, se encuentra en el Digesto 19.2.60.4, el cual señala: "Te mandé que vieses por cuánto querrías edificar una casa de campo; me dijiste que habías visto que por un gasto de doscientos; te di en arrendamiento la obra por cierta retribución, y después averigüé que no podía costar la casa de campo menos de trescientos, pero se te habían dado cien, y habiendo gastado parte de ellos, te prohibí que hicieras la obra, ejercitaré contra ti la acción de locación, para que me restituyas lo restante del dinero" (la traducción es de GARCÍA DEL CORRAL (1889), p. 970). En este sentido, RodríGuez (1991), pp. 314-315.

Si bien la norma justinianea se asemeja a estas disposiciones, actualmente la doctrina mayoritaria considera que la estimación deficitaria del costo de la obra constituye un incumplimiento contractual del artífice, por ser inherente a su función empresarial. Así, Martínez Velencoso (2003), p. 273.

${ }^{51}$ Rezzonico (1959), p. 823.

${ }^{52}$ Planiol y Ripert (1991), p. 399.

${ }^{53}$ LÓPEZ (2015), p. 161.

${ }^{54}$ Baraona (1997), pp. 156-157. Véase también Llamas Pombo (1999), pp. 140-143 y 244 y Contardo (2015), p. 47 y s. En contra, Cristóbal Montes (1989), pp. 229-230, PANTAleón (1991), pp. 1020 y s. y LóPez (2015), p. 167, todos los cuales propugnan, de un modo u otro, la unidad del fenómeno resarcitorio. 
En este sentido, cabe acotar que la misma doctrina francesa posterior a la Escuela de la Exégesis reconoció abiertamente esta función de reparación de la responsabilidad contractual, que, con algunas críticas, perdura hasta nuestros días ${ }^{55}$. Lo anterior no debiera parecer extraño, puesto que los orígenes de la distinción entre el valor de la prestación y los daños consecuenciales se encuentran presentes, incluso, desde el pensamiento de Robert Pothier ${ }^{56}$.

De este modo, todo parece indicar que el art. 1794 del $C C$ fra, al limitar los efectos de la cesación al valor de la prestación frustrada, no da origen a una auténtica indemnización de perjuicios. Parte de la doctrina gala también lo ha entendido de este modo. Así fluye, entre otros, de Louis Josserand, quien distingue entre las obligaciones que surgen para el mandante como consecuencia de la cesación de la obra y aquellas que, por ejemplo, debe el patrón al obrero en caso de terminación abusiva del contrato $^{57}$. Y, desde luego, aquellas no cubren los gastos en que el artífice no incurrió por la obra cesada ni, menos, las ganancias que podrían haber surgido de obras paralelas a la contratada.

\section{El ART. 1999 DEL $C C$ Y SU INSERCIÓN EN EL CÓDIGO.}

El $C C$ reconoce cuatro tipos de arrendamiento:

- de cosas (con reglas particulares tanto para las casas, almacenes u otros edificios, como para los predios rústicos),

- confección de una obra material,

- de servicios inmateriales

- y de transporte, sin considerar las normas sobre arrendamiento de criados domésticos, que se encuentran actualmente derogadas y $\sin$ aplicación $^{58}$.

${ }^{55}$ Pizarro (2004), p. 85.

${ }^{56}$ Llamas Pombo (1999), pp. 140-143.

${ }^{57}$ Josserand (1951), p. 245.

${ }^{58} \mathrm{El}$ art. 1915 del $C C$ define el arrendamiento como el "contrato en que las dos partes se obligan recíprocamente, la una a conceder el goce de una cosa, o a ejecutar una obra o prestar un servicio, y la otra a pagar por este goce, obra o servicio un precio determinado". La regulación del arrendamiento de cosas se extiende entre los arts. 1916 y 1986 del $C C$, incluyendo las disposiciones sobre casas, almacenes u otros edificios (arts. 1970 a 1977 del $C$ C), predios rústicos (arts. 1978 a 1986 del $C$ C). Por su parte, los contratos para la confección de una obra material se contemplan entre los arts. 1996 y 2005 del $C C$. El arrendamiento de servicios inmateriales se regula entre los arts. 2006 y 2012 del $C C$ y el de transporte, entre los arts. 2013 y 2021 del CC. El arrendamiento de criados domésticos se encontraba regulado entre los arts. 1987 y 1995 del $C C$. 
La cesación resulta aplicable, por disposición expresa, tanto en los contratos de confección de obra material como en los de servicios inmateriales $(\text { art. } 2006 \mathrm{del} C C)^{59}$, extendiendo notablemente su ámbito de aplicación ${ }^{60}$.

Como señalamos, el lazo entre el art. $1794 \mathrm{del} C C$ fra y el art. 1999 del $C C$ resulta indiscutible. Con todo, la norma chilena está lejos de ser una mera reproducción de la disposición francesa. Por lo pronto, Andrés Bello extrajo de la disposición del $C C$ fra dos reglas distintas, que ubicó separadamente en los dos incisos del actual art. 1999 del $C C$. La primera es la regla indemnizatoria del contrato de obra. La segunda, la regla de la cesación.

\section{La regla indemnizatoria del art. 1999 inc. $1^{\circ}$ del CC}

Conforme con esta disposición, en el contrato de confección de obra material hay derecho al resarcimiento, según las reglas generales de los contratos, "siempre que por una o por otra parte no se haya ejecutado lo convenido, o se haya retardado su ejecución”. El supuesto de hecho lo constituye el incumplimiento contractual, o, como se ha definido modernamente, "cualquier desviación de las exigencias del contrato en el desenvolvimiento o ejecución del mismo" ${ }^{61}$. Por lo tanto, su verificación opera en términos objetivos, y "consiste en comparar la conducta esperable según el contrato y aquella que efectivamente se produjo en la realidad" 62 .

Este remedio resarcitorio se encuentra a disposición de cualquiera de los contratantes y su ejercicio no va ligado ni al cumplimiento ni a la resolución del contrato ${ }^{63}$. En todo caso, la indemnización no priva al mandante del

${ }^{59}$ Art. 2006 del $C C$ : "Las obras inmateriales, o en que predomina la inteligencia sobre la obra de mano, como una composición literaria, o la corrección tipográfica de un impreso, se sujetan a las disposiciones especiales de los artículos 1997, 1998, 1999 y 2002". En relación con la terminación anticipada en este tipo de contratos, véase Román Canales con Televisión Nacional de Chile (2016), en especial el considerando tercero de la sentencia de reemplazo.

${ }^{60}$ En el $C C$ fra no existe una norma expresa que extienda la cesación a las prestaciones de servicios, cuestión que se repite en otros ordenamientos herederos de la tradición francesa, como el español. En todo caso, de un tiempo a esta parte, la doctrina se ha mostrado proclive a ampliar el espectro de la regla a estos contratos, considerando la estrecha relación sistemática con la confección de obra material. Por todos, véase MACANÁS (2014), p. 219 y s. Cabe señalar que el DCFR, IV.C.-2:111, establece también para el contrato de servicios, la facultad del comitente de terminar el contrato ad nutum una vez notificado de forma recepticia a la contraparte.

${ }^{61}$ Morales Moreno (2006), p. 29.

${ }^{62}$ Corral (2010), p. 154.

${ }^{63} \mathrm{El}$ art. 1999 inc. $1^{\circ}$ del $C C$ sigue la regla general dispuesta por el art. 1553 del $C C$ para las obligaciones de hacer. Se trata de uno de los supuestos en que expresamente se resuelve la cuestión de la autonomía indemnizatoria en el CC a su favor. En el caso de las obligaciones de dar, sin embargo, no existe unanimidad sobre esta materia. 
derecho para obligar al artífice a hacer de nuevo la obra si ésta no se ha ejecutado debidamente (art. $2002 \mathrm{del} C C)^{64}$, ni tampoco de la resolución ${ }^{65}$. En cuanto a sus presupuestos, el art. 1999 inc. $1^{\circ}$ del $C C$ remite a las "reglas generales de los contratos". Al efecto, tradicionalmente se ha entendido que la responsabilidad contractual requiere de: incumplimiento (el cual, como se apuntó, puede provenir de cualquiera de los contratantes), imputabilidad del incumplimiento al deudor ${ }^{66}$, constitución en mora,

Para una postura tradicional, que podemos representar en Alessandri (1988a), p. 76, la indemnización de perjuicios constituye un remedio subordinado al cumplimiento o a la resolución del contrato, salvo en las obligaciones de hacer y no hacer, en las que existen disposiciones expresas que facultan al acreedor insatisfecho para deducirlas autónomamente (arts. 1553 y $1555 \mathrm{del} C C$ ). El argumento reside en el tenor literal del art. 1489 inc. $2^{\circ}$ del $C C$, según el cual, ante el incumplimiento del deudor, el acreedor puede pedir a su arbitrio la resolución o el cumplimiento del contrato "con" la indemnización.

Para la doctrina moderna, en cambio, el acreedor no se encuentra atado jerárquicamente por las acciones contenidas en el $C C$. Conforme a lo anterior, el acreedor puede optar por aquel remedio que mejor cuadre con el interés que pretenda satisfacer. En definitiva, el acento se coloca en la satisfacción del propósito práctico que el acreedor busca como resultado del negocio y no en la posición jurídica del deudor. En este sentido, se pronuncian Pizarro (2009), p. 214 y s.; Bahamondes (2011), p. 235 y s. y LóPez (2015), p. 257 y s.

Esta comprensión del remedio resarcitorio ha ganado terreno en la jurisprudencia de la Corte Suprema. Al respecto, pueden verse: Zorín S.A. con Compañía Siderúrgica Huachipato S.A. (2012), Stange Hoffman Eduardo con Ripley Puerto Montt (2013) y Laboratorios de Control Técnico Llay Llay Ltda. con Celestron Ltda. (2014).

${ }^{64}$ Art. 2002 del $C C$ : "Si el que encargó la obra alegare no haberse ejecutado debidamente, se nombrarán por las dos partes peritos que decidan. Siendo fundada la alegación del que encargó la obra, el artífice podrá ser obligado, a elección del que encargó la obra, a hacerla de nuevo o a la indemnización de perjuicios. La restitución de los materiales podrá hacerse con otros de igual calidad o en dinero".

Si bien algunos entienden que esta disposición se encuentra derogada, por aludir a la antigua institución de los juicios prácticos -actualmente sin aplicación en nuestro ordenamiento jurídico con ocasión de la derogación tácita de estos por el artículo 177 del Código Orgánico de Tribunales-, a partir de un fallo reciente de la Corte Suprema parece indiscutible su plena vigencia. Véase Corporación Nacional del Cobre de Chile, Codelco Chile, División Codelco Norte con Consorcio Constructora Araneda Brain Chile Ltda. (2015).

${ }^{65}$ Contardo (2015), p. 367.

${ }^{66}$ Respecto a la imputabilidad por culpa, podemos constatar su progresivo declive como elemento de la responsabilidad contractual. Una primera manifestación de lo anterior la constituye la objetivación de la culpa, en el sentido expuesto por PANTALEón (1993), pp. 1737-1745, aunque sin desdeñar por completo de ella. En la actualidad, algunos entienden que la culpa ni siquiera constituye un presupuesto de la responsabilidad contractual. Así puede leerse, en Chile, en autores como Baraona (1997), p. 151 y s.; Peñailillo (2009), p. 338 y AlCALde (2011), p. 623 y s.

En la Propuesta de Modernización del Derecho de Obligaciones y Contratos elaborada en España, la culpa deja de ser un requisito de la pretensión indemnizatoria. El simple incumplimiento permite al acreedor pedir el resarcimiento. En este sentido, véase MorALES Moreno (2014a), p. 31. 
causalidad, y existencia y prueba de los perjuicios ${ }^{67}$. De estos, no cabe duda que el incumplimiento constituye el elemento fundacional sobre el cual se erige la responsabilidad del deudor ${ }^{68}$. Por el contrario, si el deudor cumple en tiempo y forma, se produce la extinción de la obligación, quedando liberado de responsabilidad.

De acuerdo con lo señalado, la indemnización presupone necesariamente que cualquiera de los contratantes se haya apartado del programa contractual trazado, causando un daño o perjuicio a los intereses de la parte insatisfecha.

\section{La cesación de la obra del art. 1999 inc. $2^{\circ}$ del CC}

Esta regla, en cambio, se refiere exclusivamente a la cesación voluntaria y facultativa de la ejecución en naturaleza del contrato. Por cierto, el empleo de la conjunción por consiguiente, que encabeza el art. 1999 inc. $2^{\circ}$ del $C C$, podría dar a entender que ella es una consecuencia de la regla contemplada en el inc. $1^{\circ 69}$. Sin embargo, en contra de esta interpretación se interponen las notables diferencias que median entre ambos preceptos.

La primera tiene relación con el sujeto activo. Según se explicó, el remedio indemnizatorio se encuentra a disposición tanto del mandante como del artífice ("siempre que por una o por otra parte"). En cambio, la cesación anticipada de la obra solo le está permitida al primero ("el que encargó la obra, aun en el caso de haberse estipulado un plazo único y total por ella").

La segunda recae en el supuesto de hecho. El remedio indemnizatorio presupone un incumplimiento contractual. La cesación, por el contrario, no implica inejecución de las obligaciones del mandante, toda vez que el reembolso de los gastos y el pago de la utilidad cumplen, en principio ${ }^{70}$, las funciones de extinción, satisfacción y liberación ${ }^{71}$, propias del cumplimiento en naturaleza del contrato de obra.

Por último, en cuanto a los efectos, la indemnización del art. 1999 inc. $1^{\circ}$ del $C C$ puede comprender los gastos incurridos, la utilidad frustrada

${ }^{67}$ Seguimos en esto a Gatica Pacheco (1959), pp. 59-60; Alessandri (1988a), p. 78 y CORRAL (2010), p. 152.

${ }^{68}$ Por todos, Jordano Fraga (1987), p. 227.

${ }^{69}$ Así lo entienden Brantt y Mejías (2016), pp. 84-85, para quienes este inciso presupone el incumplimiento contractual y el reconocimiento del derecho a la indemnización de perjuicios como remedio al acreedor.

${ }^{70}$ Sin perjuicio de lo que se dirá más adelante respecto a la cesación ejercida contrariando la buena fe. Véase infra $\mathrm{V}$.

${ }^{71}$ BARAONA (1998), p. 93. 
(valor de la prestación) ${ }^{72}$, como cualquier otro daño a un interés legítimo del acreedor, determinado por la regla contractual ${ }^{73}$. Por el contrario, la cesación típicamente se circunscribe al reembolso de los gastos y a la utilidad de la obra ${ }^{74}$, sin extensión de ninguna especie ${ }^{75}$.

La técnica empleada en el $C C$ chileno contrasta también con la construcción del art. 1794 del $C C$ fra. Como se indicó ${ }^{76}$, esta norma impone la obligación de indemnizar al artífice "todos sus gastos, todos sus trabajos y toda utilidad que pudiera haber obtenido en esta obra", lo que respondería a una impropiedad del legislador francés, puesto que estos efectos no constituyen daños consecuenciales que van más allá del valor de la prestación. A lo anterior debemos agregar que en el sistema general de responsabilidad contractual del $C C \mathrm{Fra}^{77}$, la indemnización de perjuicios se apoya en el incumplimiento ${ }^{78}$.

Por el contrario, el art. 1999 inc. $2^{\circ}$ del $C C$ no ocupa la voz 'indemnizar'. El que encargó la obra puede hacerla cesar, reembolsando al artífice los costos y dándole lo que valga el trabajo y utilidad que hubiera podido ganar en la obra. Nada indica que Andrés Bello haya empleado estos términos al azar. En la sistemática del $C C$ el reembolso no opera ante un incumplimiento contractual, sino para los efectos de volver una cantidad al poder de quien la había desembolsado. Así ocurre, por ejemplo, en el mandato (art. $2158 \mathrm{del} C C)^{79}$ y la fianza (art. 2370 del $\left.C C\right)^{80}$. Además,

${ }^{72}$ En este sentido, CONTARDo (2015), pp. 367-368 sostiene que el incumplimiento total de la obligación del artífice permite al cocontratante obtener la diferencia entre el valor de reemplazo o de mercado por la prestación. Si la acción es deducida por el primero, en caso de disminución del precio del reemplazo o del valor de mercado del trabajo correspondiente a la obra, obtendrá la diferencia.

${ }^{73}$ Morales Moreno (2014b), p. 111.

${ }^{74}$ Véase infra III. 3.

${ }^{75}$ En este sentido, en una ocasión nuestro máximo tribunal rechazó la demanda deducida por un contratista, que pretendía el reembolso de los gastos de arrendamiento de oficinas y honorarios de calculistas y dibujantes, por considerarlos comprendidos en el honorario que debía pagarse a aquel. Además, no existía pacto expreso para dicho cobro. Véase Tupper y otro con Polla Chilena de Beneficencia (1962).

${ }^{76}$ Véase supra II. 2.

${ }^{77}$ Nos referimos en especial a los antiguos artículos 1136, 1142 y 1146 a 1155 del CC fra, y a los nuevos 1217, 1221, 1223, 1224 y 1231 del $C C$ fra, respectivamente.

${ }^{78}$ Por todos, Gaudemet (2010), p. 403.

${ }^{79}$ En efecto, esta disposición impone al mandante dos prestaciones perfectamente diferenciadas: el reembolso de todos los gastos razonables causados por la ejecución del mandato ( $\left.\mathrm{N}^{\mathrm{o}} 2\right)$, y la indemnización de las pérdidas en que el mandatario haya incurrido sin culpa y por causa del mandato ( $\left.\mathrm{N}^{\mathrm{O}} 5\right)$.

${ }^{80} \mathrm{El}$ art. $2370 \mathrm{del} C C$, por su parte, contrapone de manera expresa la acción de reembolso, que da derecho a pedir al deudor principal lo que el fiador haya pagado por él con intereses y gastos $\left(\right.$ inc. $1^{\circ}$ ), con el derecho a la indemnización de perjuicios, disciplinado "según las reglas generales" (inc. $2^{\circ}$ ). 
Andrés Bello en forma expresa habla de dar lo que valga el trabajo hecho y la utilidad, lo que tampoco debe extrañarnos, si consideramos que la obligación de pagar el precio constituye, precisamente, una obligación de dar. Por otra parte, no debemos olvidar que de acuerdo con el art. 1558 del $C C$ la indemnización de perjuicios proviene del no cumplimiento, del cumplimiento imperfecto o del retardo en la ejecución.

Dicho de otro modo, la técnica utilizada por Andrés Bello en relación con los efectos de la cesación, la alejan del remedio indemnizatorio, acercándola más a los que resultan del cumplimiento de las obligaciones contraídas por el mandante en el acto constitutivo del vínculo contractual.

En conclusión, si bien el legislador no dejó una nota que explique esta disquisición ${ }^{81}$, podemos conjeturar que deliberadamente depuró ambas reglas -la indemnizatoria y de cesación de la obra- para refrendar que esta última no constituye un incumplimiento contractual que dé origen a una indemnización de perjuicios. Esto podría explicar que a su respecto no haya utilizado la expresión 'indemnizar' ${ }^{\prime 2}$. Veremos luego que esto trae consigo una importante consecuencia: la posibilidad de sumar al valor de la prestación la indemnización de los daños extrínsecos (id quod interest) cuando el ejercicio de la cesación haya sido contrario a la buena $\mathrm{fe}^{83}$.

${ }^{81}$ En todo caso, cabe notar que en el Código Civil de Luisiana del año 1825 -que Andrés Bello tuvo a la vista a través de la obra de Antoine de Saint Joseph, sobre el $C C$ fra y sus concordancias con otras codificaciones- ambas reglas, la de la cesación de la obra y la indemnizatoria, se encuentran recogidas en disposiciones separadas, de un modo similar al $C C$. Nos referimos a los arts. 2736 y 2740 , respectivamente.

El primero de ellos dispone: "The proprietor has a right to cancel at pleasure the bargain he has made, even in case the work has already been commenced, by paying the undertaker for the expense and labor already incurred, and such damages as the nature of the case require". Por su parte, el segundo señala: "If an undertaker fails to do the work he has contracted for, or if he does no execute it in the manner, and at the time he has agreed to do it, he shall be liable in damages for the losses that may ensue from his noncompliance with his contract”. Véase SAINT JoSEPH (1852), p. 145. Respecto al empleo de esta fuente en el trabajo de Andrés Bello, véase Lira Urquieta (1956), p. 76.

${ }^{82}$ Aun cuando la jurisprudencia sobre la materia es escasa, es posible encontrar fallos en que expresamente se reconoce el distingo de las reglas contenidas en el art. 1999 del CC. Por ejemplo, en Club Hípico de Santiago con Koslan S.A.(2013), se puede leer: "El tenor literal de la disposición en comento lleva a concluir que se regulan en ella dos hipótesis; el inciso primero dispone que habrá lugar a la indemnización de perjuicios cuando la obra 'no se haya ejecutado o se haya retardado su ejecución', por tanto, la obligación que contrae el artífice no es otra que ejecutar la obra en la forma y plazo convenidos y si así no lo hiciere se le aplicarán las reglas generales relativa al incumplimiento contractual. El inciso segundo, contempla una causal especial de extinción del contrato, pues quien encargó la obra podrá hacerla cesar por su sola voluntad, debiendo reembolsar al artífice todos los costos y dándole, lo que valga el trabajo hecho y lo que hubiere podido ganar en la obra, aunque ésta haya comenzado (...)".

${ }^{83}$ Véase infra $\mathrm{V}$. 


\section{Efectos particulares de la cesación}

En términos amplios, la cesación provoca la extinción del contrato de confección de obra, liberando al artífice de su obligación de ejecutarla y al mandante de pagar el precio. De este modo, las partes entran en una fase de liquidación de las obligaciones emanadas del contrato. No obstante, la mera formulación general del efecto extintivo del contrato impide comprender las peculiaridades de esta figura. Para ello, nos referiremos a continuación a los efectos particulares que emanan de su ejercicio de buena fe por parte del mandante.

\section{a) Extinción de las obligaciones contractuales del artífice}

Interrumpida la obra, expira definitivamente su deber de cumplir la obligación de ejecutarla en la forma convenida en el contrato. La circunstancia que provoca esta extinción, en palabras de Albert Lamarca, está constituida por un hecho del acreedor que imposibilita la prestación ${ }^{84}$. Y esta extinción no solo comprende la obligación principal de llevar a cabo la obra sino que todo el plexo de deberes que la circunda (por ejemplo, la provisión de materiales, contratación de mano de obra, obtención de permisos, etc.). Solo se exceptúan aquellos que derivan del deber de actuar de buena fe en el ámbito poscontractual (como el deber de confidencialidad, la restitución de herramientas y del material acopiado que haya sido adquirido por el mandante ${ }^{85}$, etcétera).

b) Extinción parcial de las obligaciones contractuales del mandante

Por el contrario, la interrupción de la obra no lo libera por completo de sus deberes contractuales. Algunas obligaciones no se ven afectadas, mientras que otras naturalmente llegan a su fin, como los deberes de colaboración, dar instrucciones, permitir el acceso a las faenas, proporcionar materiales, etcétera.

Las obligaciones que no son alteradas por la cesación, son las siguientes:

${ }^{84}$ En efecto, comentando el supuesto del art. 1594 del $C C$ esp, Lamarca (2001), p. 143, sostiene: "el dueño de la obra puede decidir que la prestación del contratista quede interrumpida definitivamente, con la obligación de dejar inmune al contratista de acuerdo con el ordinario cumplimiento de su prestación, es decir, proceder como si el contrato se hubiera cumplido". En un sentido similar, véase GÁlvez (2008), p. 41.

${ }^{85}$ En este sentido, De Los Mozos (1965), pp. 227-228. 


\section{i. Reembolso de los costos}

Entendemos por gastos de la obra todo desembolso efectuado por el artífice en consideración a la obra, como jornales o materiales ${ }^{86}$. El reembolso se limita a las partidas generadas con anterioridad a la fecha de la cesación. Por lo anterior, una vez comunicada, el artífice debe abstenerse de incurrir en nuevos gastos. Si estos se originan después de la fecha en que el artífice tomó conocimiento de la cesación, son de su exclusiva responsabilidad.

Finalmente, cabe puntualizar que los gastos reembolsables únicamente se refieren a las obras ejecutadas y no a las obras por ejecutar. En cuanto a estas últimas, el mandante solo queda obligado al pago del lucro que el artífice habría podido obtener con ellas ${ }^{87}$.

\section{ii. Pago de la utilidad}

La utilidad está constituida por el beneficio que hubiera obtenido el contratista de haber realizado la totalidad de la obra, que lo coloca en la misma posición económica que hubiera resultado de la normal conclusión del contrato ${ }^{88}$. Un sector de la doctrina ha entendido que esta representa un lucro cesante, en el contexto de un supuesto de responsabilidad civil que no importa un incumplimiento contractual del artífice ${ }^{89}$. Por nuestra parte, estimamos que el pago de la utilidad equivale al interés positivo de este $^{90}$, ya que representa exactamente la contraprestación del mandante, sin extenderse a daños extrínsecos o consecuenciales. Esta tesitura reafirma que, cesada la obra, su efecto automático no compone una auténtica indemnización de perjuicios ${ }^{91}$, ya que el contratista queda en la misma posición que en la que se hubiese situado con el cumplimiento en naturaleza del contrato ${ }^{92}$.

Esta conclusión es relevante en dos sentidos. El primero, que hemos adelantado, es la reafirmación de que el mandante que hace cesar la obra no incurre en un auténtico incumplimiento contractual, por cuanto el pago de la utilidad equivale al interés proyectado en el contrato y cuya satisfacción pretende el artífice ${ }^{93}$. El segundo, es que esta figura no cons-

${ }^{86}$ VAQUero (2005), p. 469.

${ }^{87}$ PRAT (1940), p. 115.

${ }^{88}$ VAQUero (2005), p. 469.

${ }^{89}$ En este sentido, Contardo (2015), pp. 366-367, quien afirma que el art. 1999 inc. $1^{\circ}$ del $C C$ regula un supuesto de incumplimiento general, y el inc. $2^{\circ}$, la responsabilidad por desistimiento unilateral del contrato.

${ }^{90}$ Seguimos en esto a Lamarca (2001), pp. 196-197.

${ }^{91}$ En contra, Brantt y Mejías (2016), pp. 84-85. Véase supra n. 69.

${ }^{92}$ Lamarca (2001), pp. 196-197.

${ }^{93}$ Por lo demás, como sostiene Pizarro (2010), p. 214, el incumplimiento no puede constituir un derecho, sino la incorrecta prestación de lo pactado 
tituye una verdadera excepción al principio del efecto obligatorio de los contratos (art. 1545 del $C C)^{94}$. Desde luego, este aserto impone alejarnos de la noción que asocia dicho principio con la irrevocabilidad absoluta del contrato ${ }^{95}$, acercándola a la idea de compromiso de satisfacción de la expectativa contractual ${ }^{96}$. En esta tesitura, el pago de la utilidad equivale a la satisfactio del acreedor/artífice, impidiendo el tránsito desde los efectos normales de las obligaciones a los efectos anormales, cuyo presupuesto esencial lo constituye el incumplimiento contractual (art. $1558 \mathrm{del} C C)^{97}$. Con las particularidades propias de cada ordenamiento, así lo ha entendido parte de la doctrina extranjera que se ha referido a la materia ${ }^{98}$.

${ }^{94}$ Como lo entienden, en cambio, Alessandri (1988b), p. 184 y Orrego (2011), p. 462. En lo que refiere al $C C$ fra, se encuentran en la misma línea Colin y CAPITANT (1925), p. 359 y Baudry-LaCANTINERie (1925), p. 469. En relación con el art. 1641 del CCita del año 1865, actual art. 1671 del $C C$ ita de 1942, véanse RicCi (s.f.), p. 389 y RugGiero (1931), p. 508. Cabe agregar que, en un comienzo, la jurisprudencia española también interpretó de este modo la disposición del art. 1594 del $C C$ esp. En este sentido, MaCanás (2014), p. 225.

${ }^{95}$ Posición que representamos en Albaladejo (2002), p. 455: "Esto cabe expresarlo diciendo que el contrato no puede revocarse por voluntad de un contratante (irrevocabilidad del contrato); que no se puede desistir unilateralmente de él. Ni tampoco es posible unilateralmente modificarlo; de manera que obliga en los términos pactados (inalterabilidad del contrato)".

${ }^{96}$ En la comprensión de BЕтті (1969), p. 114, la satisfacción del interés se construye desde la buena fe. Este principio "se podría caracterizar como un criterio de conducta que se funda sobre la fidelidad del vínculo contractual y sobre el compromiso de satisfacer la legítima expectativa de la otra parte: un compromiso en poner todos los recursos propios al servicio del interés de la otra parte en la medida exigida por el tipo de relación obligatoria de que se trate; compromiso en satisfacer íntegramente el interés de la parte acreedora a la prestación". Véase también Terraza (1951), pp. 27-28.

${ }^{97}$ En este sentido, Vidal (2006), p. 177.

${ }^{98}$ Por ejemplo, García Goyena (1852), p. 486, al explicar el art. 1535 del proyecto isabelino que sirvió de base para el actual $C C$ esp, señala: "Ningún perjuicio se irroga por el artículo al arquitecto o empresario, pues, se le da todo lo que podría tener después de concluida la obra; y al mismo tiempo se evita que el propietario, cuya fortuna se halle comprometida repentinamente por sucesos imprevistos, se arruine completamente con gastos en estremo dispendiosos. Puede también ocurrir que la obra no le sea ya útil ni necesaria”. En igual sentido, respecto al art. 1594 del $C C$ esp, Puig Brutau (1956), p. 399, señala: "el interés sustancial del contratista en la realización de la obra queda completamente satisfecho y el comitente puede ahorrarse la diferencia que, por encima de la ganancia neta del artífice, representaría el gasto de ejecución total de la obra". También es la opinión de Borda (1997), p. 112 y s., a propósito del art. 1638 del $C C$ ar (actual art. 1261 del $C C$ ar). En su concepto, si bien esta facultad constituye una excepción al principio general según el cual los contratos no pueden ser dejados sin efecto sino por voluntad común de los contratantes, en rigor "es una derogación sólo aparente, pues como al desistir el dueño debe indemnizar al empresario de todos los gastos y ganancias que esperaba obtener de la obra, en verdad él cumple con todo lo que había prometido limitándose a renunciar a los beneficios que podía esperar del contrato". 
Esto resulta relevante para comprender el ámbito de aplicación de la figura, ya no entendida como una regla excepcional ${ }^{99}$ y de interpretación restrictiva.

A partir de lo expuesto aún subsiste una interrogante. Si el incumplimiento contractual no constituye el supuesto típico de la cesación, debemos preguntarnos, ¿cuáles son los casos en que naturalmente el mandante puede poner término anticipado a la obra? Para adentrarnos con mayor precisión en este tema, previamente nos referiremos a la regulación de los riesgos en el contrato de confección de obra material.

\section{LA REGULACIÓN DEL RIESGO}

EN LOS CONTRATOS PARA LA CONFECCIÓN DE UNA OBRA MATERIAL

Conforme al art. 1996 del $C C^{100}$, el contrato de confección de obra material puede constituir compraventa o arrendamiento, según la parte que suministre los materiales. Habrá compraventa cuando son aportados por el artífice, y arrendamiento si ello toca al mandante (incs. $1^{\circ}$ y $3^{\circ}$ ). Si la materia principal ${ }^{101}$ es suministrada por este último, poniendo el artífice lo

En relación con el art. 2056 del $C C$ co, idéntico a nuestro art. 1999 del $C C$, Molina (2014), pp. 299-300, señala que su peculiaridad consiste en que autoriza retractarse a quien encargó la obra, lo que bajo otra perspectiva bien podría considerarse como un incumplimiento del contrato. Lo que hace que el caso analizado sea de retractación y no de una simple estimación anticipada de perjuicios por incumplimiento, afirma, lo determina el derecho conferido a la parte contratante de la obra. Así, su decisión de hacer cesar la obra es ajustada a Derecho. En cambio, si el contratista por su propia iniciativa optare por no ejecutar la obra, estaría incumpliendo el contrato. La misma doctrina ha sido suscrita por LARENZ (1959), pp. 322-323 y ENNECCERUs (1966), p. 550, en relación con el § 649 del BGB.

${ }^{99}$ Lo que, en todo caso, no implica que la consagración positiva de esta figura resulte del todo irrelevante. En este sentido, existen voces, como la de Ricci (s.f.), p. 390, que sostienen que la utilidad de la regla no debe ser subestimada, por cuanto: "si el legislador hubiera hecho mal en no conceder la resolución, lo cierto es que el intérprete no hubiera podido concederla, por ruinoso que fuera el contrato".

${ }^{100}$ Art. 1996 del $C C$ : "Si el artífice suministra la materia para la confección de una obra material, el contrato es de venta; pero no se perfecciona sino por la aprobación del que ordenó la obra. Por consiguiente, el peligro de la cosa no pertenece al que ordenó la obra sino desde su aprobación, salvo que se haya constituido en mora de declarar si la aprueba o no. Si la materia es suministrada por la persona que encargó la obra, el contrato es de arrendamiento. Si la materia principal es suministrada por el que ha ordenado la obra, poniendo el artífice lo demás, el contrato es de arrendamiento; en el caso contrario, de venta. El arrendamiento de obra se sujeta a las reglas generales del contrato de arrendamiento, sin perjuicio de las especiales que siguen”.

${ }^{101}$ Para una comprensión de lo que se entiende por "materia principal" y la normativa aplicable al contrato de compraventa de obras antes de su perfeccionamiento, véase SAN MARTín (2015), p. 751 y s. 
demás, el contrato es de arrendamiento y, en caso contrario, venta (inc. $4^{\circ}$ ). $\mathrm{El}$ arrendamiento de obra se rige por las "reglas generales del contrato de arrendamiento" y, en especial, por aquellas que se contienen en los arts. 1997 a 2005 del $C C$ (inc. $5^{\circ}$ ).

Por regla general, las obligaciones que emanan de este contrato no se cumplen instantáneamente. Antes, al contrario, la ejecución de una obra constituye una relación obligatoria duradera, cuyo desenvolvimiento supone un tiempo más o menos prolongado ${ }^{102}$, dentro del cual el artífice debe ejecutar y concluir el trabajo. El tiempo de la prestación no se corresponde con la duración del acto de cumplimiento, sino con su formación, el cual requiere una actividad que se prolonga durante un cierto periodo, hasta que finalmente se perfecciona. Solo en ese momento, con el resultado final, se produce la satisfacción plena del interés del mandante, que es por tanto instantánea ${ }^{103}$.

Por otra parte, el contrato de confección de obra se aparta del efecto normal o natural de las obligaciones bilaterales en cuanto refiere a la simultaneidad en la ejecución de las prestaciones ${ }^{104}$. En efecto, típicamente al menos, por cuanto admite derogación convencional por las partes, el contrato de obra supone que el artífice ejecuta en forma anticipada su prestación, mientras que la del mandante -constituida esencialmente por el pago del precio 30 convenido- se hace exigible con la conclusión y aprobación de la obra ${ }^{105}$.

Estas características -ejecución prolongada y no simultaneidad de las obligaciones- determinan que el contrato de obra se exponga a una serie de contingencias sobrevenidas ${ }^{106}$, que incrementan el riesgo de insatisfacción de la operación económica proyectada en el plan contractual ${ }^{107}$. La interrogante, entonces, es, ¿cuál de los contratantes soporta las vicisitudes, los riesgos o los peligros de la contratación cuando el intercambio no es inmediato y simultáneo? ${ }^{108}$.

La respuesta se encuentra al interior del contrato, el cual dibuja un mapa de distribución de riesgos, incluyendo todos los elementos involu-

102 Díez-Picazo (2008), pp. 365-366.

${ }^{103}$ KLEIN (1997), pp. 68-69.

${ }^{104}$ Díez-Picazo Giménez (1996), p. 559.

${ }^{105}$ En este sentido, SánCHez (1978), p. 245; Fernández (1996), pp. 410-411 y FisaC DE RON (2001), p. 107.

${ }^{106}$ Castilla (2000), p. 443. También Posner (2013), p. 160.

${ }^{107}$ Siguiendo la formulación de Gavidia (1987), p. 584, entendemos por riesgo contractual el peligro de insatisfacción de los intereses o de la frustración de las expectativas que una o ambas partes habían pretendido realizar con la puesta en marcha de la operación económica regida por el contrato, como consecuencia de la existencia de ciertas circunstancias o de la sobrevivencia de ciertos eventos alteradores del programa económico de los contratantes.

${ }^{108}$ Mosset y Piedecasas (2008), p. 28. 
crados en la producción de los resultados esperados por las partes ${ }^{109}$. Tomando las reflexiones de Ernst Rabel -recogidas definitivamente en la CISG-110, en toda relación jurídico-contractual pueden visualizarse tres esferas de riesgos:

- La primera corresponde al riesgo típico del deudor, representada por su empresa y organización, dentro de la cual su responsabilidad es absoluta y no admite exoneración de ningún tipo. Este ámbito de influencia se define objetivamente ${ }^{111}$ e involucra todas las medidas de organización y control que de manera razonable debe adoptar el deudor para el aseguramiento de la expectativa contractual del acreedor. Abarca, por lo tanto, sus elementos personales y de los individuos que integran su organización, y aquellos bienes indispensables para la ejecución del contrato ${ }^{112}$.

- La segunda la componen aquellos impedimentos que, no obstante encontrarse fuera de la esfera típica, pueden controlarse por el deudor sobre la base de las siguientes reglas: primero, la razonable previsión al momento de contratar, desplegando su eficacia con independencia de su real posibilidad de $\operatorname{control}^{113}$, de modo que el deudor es responsable por no haberlos excluido en forma expresa mediante un acto de autonomía privada, y segundo, la razonable posibilidad de evitar o superar el impedimento imprevisible o sus consecuencias ${ }^{114}$.

- Por último, la de los terceros que, sin formar parte de la estructura organizativa del deudor, lo auxilian independientemente para el cumplimiento de sus obligaciones ${ }^{115}$.

Esta distribución típica del riesgo se percibe con intensidad en la relación contractual de obras, por la mutabilidad de las circunstancias propia de una vinculación duradera ${ }^{116}$. Existe, en consecuencia, un riesgo típico del artífice/deudor, conforme al cual su responsabilidad es absoluta y no puede excusarse de cumplir la obra. Ella se refleja en la pérdida de los materiales que se proveen para su ejecución. El art. 2000 inc. $1^{\circ} \operatorname{del} C C$ establece a este respecto el principio general: "La pérdida de la materia recae sobre su dueño" 117 , disposición aplicable tanto si la confección se

${ }^{109}$ García (2014), p. 152. También Baraona (1998), pp. 198-200.

${ }^{110}$ Arts. 74 a 79. En este sentido, Pantaleón (1993), p. 1061 y ss.

${ }^{111}$ Vidal (2006), pp. 40-41.

${ }^{112}$ Vidal (2006), passim.

${ }^{113}$ Alcalde (2008), p. 62.

${ }^{114}$ Ibid.

${ }^{115}$ Salvador Coderch (2006), pp. 648-651.

${ }^{116}$ En este sentido, Galgano (1992), p. 150.

${ }^{117}$ Cabe señalar que en España, tanto BAdosa (1987), pp. 210-214 como Solé (1997), 
califica como compraventa (arts. 1996 inc. $2^{\circ}$ y 2000 inc. $2^{\circ}$ del $C C$ ) como si esta corresponde a un arrendamiento de obra (art. 1996 inc. $3^{\circ}$ del $C C$ ), incluyendo la aportación mixta (inc. $\left.4^{\circ}\right)$. Su responsabilidad plena por la pérdida de los materiales se extiende a la pérdida culpable de los materiales aportados por el mandante (art. 2000 inc. $2^{\circ} \mathrm{del} C C$ ), a la pérdida fortuita (inc. $3^{\circ}$ ) e, incluso, si la cosa perece por un vicio de la materia suministrada por este, cuando "el vicio sea de aquellos que el artífice por su oficio haya debido conocer, o que conociéndolo no haya dado aviso oportuno" (art. $2000 \mathrm{~N}^{\mathrm{o}} 3^{\circ}$ del $C C$ in fine). En todos estos supuestos, la obligación no se extingue. Por el contrario, él permanece obligado a ejecutar la obra en los términos pactados ${ }^{118}$. La pérdida de la materia solo producirá la extinción de la obligación en circunstancias calificadas como, por ejemplo, cuando es irremplazable ${ }^{119}$.

En lo que exceda a esta esfera típica, el artífice/deudor responderá de todas aquellas contingencias previsibles y que no fueron excluidas al momento de contratar, así como de las que, siendo imprevisibles, razonablemente puede controlar. Si este no logra sobreponerse a esos impedimentos, incumple el contrato, operando en toda su extensión la regla indemnizatoria prevista en el art. 1999 inc. $1^{\circ}$ del $C C$ en favor del mandante/ acreedor. Como señalamos, en el acto constitutivo de la obligación, el artífice puede limitar su responsabilidad. Pero, en caso contrario, la falta de consecución del resultado garantizado por el deudor al acreedor, se amplía a todas las circunstancias fácticas, presupuestas y garantizadas por el contrato que no se verifiquen en la realidad ${ }^{120}$.

Finalmente, la tercera esfera envuelve la responsabilidad del artífice por todos los auxiliares a los cuales haya recurrido para la ejecución de la obra. A este respecto, el art. $2003 \mathrm{~N}^{\mathrm{o}} 5 \mathrm{del}$ CC in fine delimita los contornos de este ámbito de control, atribuyéndole la responsabilidad directa por aquellos subcontratistas que hayan contratado con él, sin perjuicio de la responsabilidad subsidiaria del mandante "hasta concurrencia de lo que éste deba al empresario" 121.

p. 25 y ss., sostienen que el motivo por el cual se atribuye el riesgo de la pérdida a quien haya aportado los materiales - ex arts. 1589 y 1590 del $C C$ esp- reside en la necesidad de encajar en una relación obligacional bilateral una regla propia de los Derechos Reales, como lo es la que se conoce con el aforismo res perit domino.

${ }^{118}$ Castilla (2000), pp. 450-454.

${ }^{119}$ Vaquero (2005), p. 99.

${ }^{120}$ Morales Moreno (2014b), p. 87.

${ }^{121}$ Art. 2003 del $C G$ : "Los contratos para construcción de edificios, celebrados con un empresario, que se encarga de toda la obra por un precio único prefijado, se sujetan además a las reglas siguientes: $5^{\mathrm{a}} \mathrm{Si}$ los artífices u obreros empleados en la construcción del edificio han contratado con el dueño directamente por sus respectivas pagas, se mirarán como contratistas independientes, y tendrán acción directa contra el dueño; pero si han 
Pero, también, la prolongación de la ejecución en el tiempo expone a la obligación a contingencias de imposibilidad sobrevenida. Como ha dicho la doctrina, la imposibilidad no se refiere a cualquier elemento de la obligación, sino a su objeto, la prestación misma ${ }^{122}$. Así, este modo de extinguir termina siendo, de igual modo, una fórmula particular de distribución de riesgos que opera en atención al contenido u objeto de la obligación ${ }^{123}$. La regulación del $C C$ distingue la cuestión de la pérdida de los materiales de la imposibilidad ${ }^{124}$ (art. 2000 inc. $3^{\circ}$ del CC). Así, por regla general, cuando la obligación del artífice se hace imposible inimputablemente, su derecho a la contraprestación correlativa se extingue. Ello determina, en consecuencia, que él soporte el periculum obligationis.

Con todo, ahí donde termina el deber de prestación del deudor, comienza indefectiblemente el riesgo del acreedor. En efecto, como afirma Ángel Carrasco ${ }^{125}$, en todos los contratos existe un riesgo de fracaso del resultado, que queda reservado a la parte activa de la obligación. En rigor, existe un riesgo dentro y fuera del contrato. El primero es aquel que se produce en el seno del programa de prestación, entre el momento de su perfección y aquel en que el contrato se agota o consume. Fuera de estos hitos temporales, el riesgo queda fuera del contrato ${ }^{126}$ y lo sufre el sujeto sobre el que cae la contingencia ${ }^{127}$. El incumplimiento del artífice -a pesar de la amplitud que se le asigna en la actualidad- ${ }^{128}$ solo se configurará como

contratado con el empresario, no tendrán acción contra el dueño sino subsidiariamente, y hasta concurrencia de lo que éste deba al empresario".

La acción directa de los subcontratistas en contra del mandante, contemplada en esta disposición -heredera directa del art. 1798 del $C C$ fra-, carece de un estudio acabado en nuestro ordenamiento. En España, DE ÁNGEL (1969), pp. 51-53, sostiene que sus presupuestos son tres: existencia de un crédito exigible de los subcontratistas en contra del artífice, falta de cumplimiento de las obligaciones para con sus subcontratistas y existencia de un crédito del mismo en contra del mandante. En todo caso, como apunta Hidalgo (2012), p. 62, el precepto parece constituir una excepción al principio del efecto relativo de los contratos en cuanto permite a un tercero dirigirse directamente contra el mandante.

${ }^{122}$ Castilla (2000), p. 28.

${ }^{123}$ AlCalde (2008), p. 72. En este sentido, entendemos por objeto de la obligación del contrato la conducta a la que, por medio del mismo, se ha obligado una parte en relación con la otra, bien sea de forma unilateral o como correlación a la conducta a la que el otro contratante se ha comprometido. Por todos, SAN Julián (1996), pp. 83-84.

${ }^{124}$ Elorriaga (2002), p. 41. Esta distinción también se encuentra presente en la clásica obra de CAPITANT (s.f.), pp. 283-285.

${ }^{125}$ Carrasco (2010), pp. 943-944.

${ }^{126}$ Op. cit., p. 964.

${ }^{127}$ En un sentido similar, Holmes JR. (1964), p. 95.

${ }^{128}$ Para el llamado moderno Derecho de Contratos, el incumplimiento es concebido como el supuesto básico en torno al cual orbita el sistema de remedios, esto es, de aquellas acciones o derechos que la ley o el contrato confieren al acreedor, entre los cuales puede 
tal en la medida en que la insatisfacción del interés del mandante suponga la falta de realización de las exigencias del contrato en cuanto hayan sido garantizadas por aquel. Por consiguiente, la exigencia de conformidad se limita a estados de la realidad que el deudor garantiza ${ }^{129}$. Lo que excede la garantía contractual -o, como ha dicho Luis Díez-Picazo, de los límites del derecho de crédito $^{130}$ - debe ser soportado por el mandante de la obra.

\section{LOS SUPUESTOS DE HECHO DE LA CESACIÓN UNILATERAL DE LA OBRA Y LIMITACIONES DE ESTA FIGURA}

\section{Los supuestos de hecho}

La doctrina, tanto nacional como extranjera, no ha sido precisa para definir el supuesto de hecho de la cesación. Desde luego, en ello ha conspirado el carácter ad nutum presente desde Robert Pothier y que, en sus palabras, no obliga al mandante a rendir cuenta al artífice ${ }^{131}$. En general, este es dibujado como un cambio imprevisto de circunstancias o fortuna que puede hacer inútil o muy gravosa la obra para el primero una vez que ha comenzado ${ }^{132}$. Es así como algunos autores aluden a un cambio de 34 circunstancias económicas que frustra su interés ${ }^{133}$, pero, otros, se refieren a la adquisición de la obra por una vía distinta ${ }^{134}$, a la imposibilidad para ejecutarla ${ }^{135}$, la pérdida de la intención de mantener la prestación por cualquier circunstancia ${ }^{136}$ e, incluso, a razones de equidad ${ }^{137}$. Otro sector es más lacónico, limitándose a transcribir la normativa legal que la consagra ${ }^{138}$.

optar, más o menos libremente, y cuyo objetivo es la realización de su interés en la prestación afectada por dicho incumplimiento. Por todos, VIDAL (2010), p. 169.

${ }^{129}$ Elizalde (2015), p. 175.

${ }^{130}$ Díez-Picazo (2008), pp. 132-133. En igual sentido LóPez (2015), p. 109 y s.

${ }^{131}$ Véase supra n. 30.

${ }^{132}$ En el Derecho español véase Castan (1988), p. 518 y KLEIN (1997), p. 89.

${ }^{133}$ En relación con el $B G B$, véase Hedemann (1958), p. 423. En cuanto al art. 1999 del $C C$, véase Meza Barros (2002), p. 281.

${ }^{134}$ Ruggiero (1931), p. 508, en relación con el art. 1641 del $C C$ ita de 1865.

${ }^{135}$ Así lo ha dicho Branca (1978), p. 427, respecto del art. 1671 del $C C$ ita de 1942.

${ }^{136}$ Rodríguez Grez (2008), pp. 82-84.

${ }^{137}$ En relación con el art. 1641 del $C C$ ita 1865 , RICCI (s.f.), p. 389. Respecto al art. 1594 del $C C$ esp, Manresa (1908), p. 763.

${ }^{138}$ En relación con el Derecho chileno, véase: De la Maza (1950), pp. 422-423, Navarro (2005), p. 204 y Barcia (2007), p. 139. Respecto al art. 1671 del CC ita de 1942, véase: BARASSI (1955), p. 257 y BARbero (1967), pp. 152-153. En cuanto al art. 1594 del CC esp, véase: Albaladejo (2002), p. 745 y Sánchez Calero (2004), p. 537. Respecto al § 649 del $B G B$, véase Loewenwarter (1935), pp. 288-289 y Medicus (1995), pp. 545-546. 
Sin embargo, a partir de la configuración del entramado de riesgos que distribuye típicamente el contrato de confección de obra -expuesto en el apartado precedente-, es posible sistematizar los supuestos de la cesación unilateral. Para ello, distinguiremos entre la cesación propia y la impropia.

\section{a) Cesación propia}

Se trata de la interrupción unilateral de la obra por el acaecimiento de cualquier evento sobrevenido que se encuentre conectado con la persona del mandante o con su ámbito de influencia y control, y que impacta en su interés y provoca su decaimiento. Como se desprende de la regulación del contrato de obra, existen presuposiciones garantizadas por el artífice, y que se entienden incorporadas en la regla contractual, y otras que escapan de ella ${ }^{139}$.

Por lo tanto, habrá riesgos que, al no formar parte de la estructura organizativa $^{140}$ y garantía de resultado -esto es, de las esferas de riesgos típica y externa de previsión y control-, deben ser administrados directamente por el mandante. En efecto, como sugiere Werner Flume,

"si la representación del declarante sobre la realidad no es parte integrante del negocio jurídico, es simplemente justo que el declarante soporte el riesgo de la corrección de sus representaciones de la realidad" 141 .

La diversidad y complejidad de impedimentos que exceden el ámbito de influencia del artífice es amplísima, lo que explica en cierto modo que, a priori, el mandante no deba justificar la cesación. De todos modos, sin pretensión de exhaustividad, creemos que estos admiten la siguiente clasificación:

\section{i. Pérdida de la confianza}

A pesar de que la confección de obra no participa históricamente de aquellos contratos de confianza stricto sensu, es innegable que esta constituye un rasgo en cierto modo común a todos los contratos ${ }^{142}$. Este alto componente fiduciario se encuentra particularmente presente en las relaciones duraderas, por la necesaria interacción de los contratantes en el desarrollo del vínculo contractual ${ }^{143}$.

${ }^{139}$ En este sentido, Aguayo (2011), pp. 412-413.

${ }^{140}$ Martínez Velencoso (2003), p. 272.

${ }^{141}$ Flume (1998), p. 580.

${ }^{142}$ D'Ors (1992), p. 143.

${ }^{143}$ Como sugiere Larenz (1958), p. 44, “exigen las relaciones de obligación duraderas, por lo general, para su ejecución una confianza recíproca y una especial observación de la 
Durante la ejecución de la obra la realidad económica del artífice puede variar, deteriorando o destruyendo las cualidades que cimentaron la confianza que el mandante le depositó en el acto constitutivo de la obligación $^{144}$. La merma de su capacidad financiera, la insolvencia, dificultades con los subcontratistas, etc., son solo algunas de las circunstancias que pueden impactar en el interés de este último. Debe tratarse, en todo caso, de situaciones objetivas que puedan constatarse por el artífice, para excluir la vía de la arbitrariedad ${ }^{145}$.

Estos supuestos no constituyen una infracción actual del resultado garantizado y, por lo mismo, la representación y proyección como una amenaza futura obliga al mandante a asumir el costo económico de la interrupción anticipada de la obra.

ii. Riesgos que el mandante administra en razón del contrato

Desde un punto de vista típico, el pago del precio estipulado es la obligación principal del mandante. Normalmente, esta constituye una obligación dineraria y, por lo tanto, resulta insensible a la impotencia financiera ${ }^{146}$. En definitiva, este contratante no puede alegar la extinción de dicha obligación como consecuencia del advenimiento de una circunstancia sobrevenida que le impida cumplir, aun cuando sea inimputable.

No obstante, no cabe duda que en algunos casos la alteración sobrevenida de las circunstancias puede afectar el importe del precio, dependiendo la modalidad acordada para su determinación. Si los contratantes configuraron la obligación como una a suma alzada, regirá la invariabilidad del precio, trasladando el riesgo económico al artífice ${ }^{147}$. Por el contrario,

diligencia en el cumplimiento de la actividad asumida, ya que en una vinculación durante largo tiempo cada una de las partes depende, más que en ningún otro caso, de la buena fe y del cumplimiento de lo convenido. De ahí que en estos casos tengan mayor significación los deberes de observar la buena fe y de la consideración personal”.

${ }^{144}$ Macanás (2015), p. 235.

${ }_{145}$ Por ejemplo, en el Derecho italiano, Iudica (2004), p. 248, sostiene, a pesar de que la cesación siempre puede ejercerse libremente, el deber de corrección impondría que se funde sobre un hecho que incida en los intereses involucrados en el contrato y que sea objetivamente referido y extensible al otro contratante. En cambio, otros autores relacionan la interdicción de la arbitrariedad con los efectos de la cesación. Así lo expresa Ruggiero (1931), p. 508: "La posible arbitrariedad de la resolución unilateral es eliminada por la obligación que la ley le impone de indemnizar al empresario por todas las obras realizadas, así como también por las ganancias que habría podido obtener de tal empresa".

${ }^{146}$ Por todos, Beltrán de Heredia (1956), p. 215 y Baraona (1998), p. 286.

${ }^{147}$ En todo caso, la doctrina no ha dudado en calificar la justicia de esta regla, atendido que la determinación del precio resulta inherente a la función empresarial del artífice. En efecto, al momento de contratar, este no solo debe tener en cuenta el posible costo de la 
si el precio es por unidad de medida o por serie de $\operatorname{precios}^{148}$, quien soportará el riesgo del aumento exponencial de los gastos del cumplimiento será el mandante. En este escenario, la cesación anticipada de la obra le permite limitar costos y evitar ulteriores perjuicios, sin afectar el interés del artífice, quien percibirá la utilidad estipulada, quedando en la misma posición como si la obra se hubiera ejecutado íntegramente.

La misma regla puede aplicarse cuando se ha producido una pérdida de los materiales aportados por el mandante o respecto del incremento de los restantes costos relacionados con la obra.

\section{iii. Riesgos que escapan de la órbita contractual}

Nos referimos a todos aquellos impedimentos que provocan una frustración del fin del contrato ${ }^{149}$, siempre y cuando no constituyan presuposiciones garantizadas contractualmente por el artífice. En estos supuestos se produce una inutilidad de la prestación a consecuencia de una circunstancia extraña a la esencia misma del contrato ${ }^{150}$ de una entidad suficiente para hacer perder la aptitud del objeto para satisfacer el interés del acreedor ${ }^{151}$. Los sucesos típicamente representativos de frustración del fin son los de cambios drásticos en la economía de un país, pérdida de negocios conexos de los cuales dependía la obra, obtención del fin por otros medios, modificaciones legales, etcétera ${ }^{152}$.

obra sino, también, todas las variaciones que, con probabilidad, puede experimentar en el curso de la ejecución. En este sentido, SÁnchez Calero (1978), pp. 227-228 y Martínez Velencoso (2003), p. 273.

${ }^{148}$ Siguiendo a URRejola (2007), pp. 19-21, entendemos por contrato por unidad de medida aquel en que no se fija un precio global por la construcción de la obra, sino que por una parte o unidad de la obra. Por contrato por serie de precio, aquella convención en que se fija precio por cada unidad de la obra entregada a su dueño o propietario.

${ }^{149}$ Se dice que finalidad contractual falla cuando la parte que aún puede realizar su prestación, y está dispuesta a ejecutarla, se encuentra ante la circunstancia inesperada de que su sacrificio económico ya no tiene interés para la otra. Esta parte, que ha perdido el interés, naturalmente se muestra resistente a realizar su propio sacrificio, ya que se impone un sacrificio que le va a reportar una ventaja en la que ya no tiene interés por una circunstancia inesperada y sobrevenida. En este sentido, ESPERT (1968), p. 172. Si bien esta teoría tiene su origen en Oertmann (1933), pp. 302-305, es con la obra de Karl Larenz sobre la base del negocio jurídico que alcanza su impulso definitivo. Véase al respecto LARENZ (1956). En al actualidad, tras la reforma del $B G B$ de 2002, la alteración de la base del negocio se encuentra regulada por el $\S 313$ del $B G B$, en el cual confluyen algunos aspectos importantes de las aportaciones de este jurista. Véanse AlbIEz (2002) pp. 1194-1195 y Martínez Velencoso (2003), p. 33.

${ }^{150}$ EsPert (1968), p. 205.

${ }^{151}$ Gianfelici (2004), p. 76.

${ }^{152}$ Cabe señalar, además, que los efectos de la cesación ex art. 1999 inc. $2^{\circ}$ del $C C$ resultan muy similares a aquellos que proyecta Karl Larenz en relación con la frustración 


\section{b) Cesación impropia}

Se trata de la interrupción anticipada del contrato de obra a la cual se aplican los efectos de la cesación propia, no obstante haberse materializado un hecho que en principio resulta encuadrable con un riesgo típicamente regulado por el legislador. En este caso no se produce un concurso, puesto que el hecho material no se rige por más de una proposición jurídica ${ }^{153}$. Tampoco lo que en España se denomina conversión de una declaración de resolución improcedente en una declaración de voluntad eficaz ${ }^{154}$. Se trata de circunstancias fácticas diferentes, que, por un acto de autonomía privada de uno de los contratantes, reciben un idéntico tratamiento.

Esto es así por el carácter ad nutum de la cesación, el cual no impide al mandante recurrir a esta herramienta, a pesar de encontrarse facultado para optar por otra vía para salvaguardar su interés. Puede suceder,

del fin del contrato en su obra. Véase Larenz (1956), pp. 183-196. De hecho, en otros ordenamientos donde también se consagra, se ha sostenido que su fundamentación radica, precisamente, en dicha teoría. En el Derecho español, por ejemplo, es la opinión de ESPERT (1968), pp. 227-228.

En el Common Law, podemos mencionar la Law Reform Frustrated Contracts Act del año 1943. Si bien sus fuentes históricas se encuentran en la jurisprudencia generada a partir de "Taylor v. Caldwell", de 1863, y en los famosos casos de la coronación del año 1902 (coronation cases), regula en términos similares la frustration, esto es, cuando deviene imposible la realización del fin u objeto del contrato. En efecto, pese a que esta permite recuperar las sumas pagadas con anterioridad al momento a partir del cual el contrato puede considerarse frustrado, si la parte a quien se le pagó o quien tendría derecho a cobrar una suma de dinero, incurrió en gastos para el cumplimiento del contrato antes del momento en que se declare la frustración, el tribunal puede permitir que retenga ese dinero o que cobre una suma compensatoria. En este sentido, RAY (1996), p. 74 y DEL Olmo (2004), p. 50.

${ }^{153}$ Larenz (1966), p. 188.

${ }^{154}$ Esta se produce cuando el mandante resuelve el contrato mediante una declaración unilateral, imputando un incumplimiento al artífice, resolución que, posteriormente en sede judicial, es calificada como una cesación ex art. 1594 del $C C$ esp, si no resulta acreditado en el proceso la inejecución. En este sentido, SAn Miguel (2004), p. 416 y s.

En Chile, la Corte Suprema se ha pronunciado en contra de la conversión, pero en la situación inversa. En efecto, en Packans Ltda. con Zhong Xiao Fan (2016), el mandante puso término extrajudicial al contrato, invocando en su favor un caso fortuito. Emepro, demandado por el artífice, esgrimió que este incumplió el contrato. Al respecto, la Corte señaló: “ $7^{\circ}$.- Que, por último, es del caso señalar que habiendo sido invocada como causal de término del contrato la fuerza mayor, no resulta procedente que el demandado se excepcione ahora en base a una causal diversa como lo es el pretendido incumplimiento de contrato del contratista, alegación que, en todo caso, sólo habría tenido incidencia para efectos de determinar los costos que irrogaría dicho incumplimiento a la fecha del respectivo avance para efectos de descontarlos del monto pendiente a pagar, según lo previene la cláusula octava del contrato, aspecto sobre el que, sin embargo, no se rindió prueba que permita dar por establecida alguna cifra por dichos conceptos". 
por ejemplo, que el artífice incumpla objetivamente las obligaciones del contrato que resultan subsumibles en su esfera típica y de control y, no obstante, prefiera terminar de manera anticipada el contrato ex art. 1999 inc. $2^{\circ}$ del $C C$. Ocurre -como advierte Richard Posner ${ }^{155}$ - que los contratantes no son neutrales al riesgo. Si el mandante sufre aversión por este, cesando la obra evitará los costos de litigación y la incertidumbre de un resultado judicial adverso. En este caso será más eficiente para él reembolsar los gastos y pagar la utilidad estipulada al artífice, de modo tal que la liberación le permita recurrir al mercado para obtener una rápida operación de reemplazo que componga el interés insatisfecho. Lo mismo puede ocurrir en aquellos casos en que la pérdida de la materia deba ser soportada por el artífice (arts. 1996 incs. $2^{\circ}$ y $4^{\circ}$, y 2000 inc. $1^{\circ}$ del $C C$ ).

\section{Limitaciones al ejercicio de la cesación}

El hecho de que el mandante no se encuentre obligado a fundamentar su ejercicio y la positivización de la figura para las obras y servicios hacen que este instrumento goce típica y potencialmente de un amplio campo de aplicación ${ }^{156}$.

No obstante, ello de ningún modo implica tolerar un ejercicio arbitrario o caprichoso ${ }^{157}$. La buena fe constituye un principio de carácter general, que opera como patrón en toda conducta jurídicamente relevante, como lo es el ejercicio de un derecho, el cumplimiento de una obligación e, incluso, en el ámbito extracontractual ${ }^{158}$.

Esto lleva a concluir que la cesación de la obra presenta una serie de limitaciones, entre las cuales podemos mencionar las siguientes:

a) Contratos cuya naturaleza impida

la cesación anticipada

Hemos dicho que, por regla general, la confección de obra material supone una relación contractual que se prolonga por un determinado espacio de

${ }^{155}$ Posner (2013), p. 860.

${ }^{156}$ Piénsese que según datos del Banco Mundial, citados por BARros Bourie (2012), p. 326, el porcentaje del PGB atribuible a servicios llega al 70\% en promedio mundial y en Chile supera el 50\%.

${ }^{157}$ En este sentido, Ordoqui (2011), p. 128, sostiene que una de las manifestaciones del principio de buena fe, consiste en el deber de no ejercer abusivamente los derechos contractuales. Así: "se exige moderación en el ejercicio del derecho que pueda derivar del propio contrato, como es el derecho de receso unilateral. Se trata de ejercer los derechos de forma justificada, y ello surge del deber de proceder con lealtad, buena fe, evitando el ejercicio abusivo del derecho".

${ }^{158}$ Por todos, Boetsch (2011), p. 77. 
tiempo, en el cual el artífice ejecuta la prestación que le encarga el mandante $^{159}$. Para que produzca sus efectos propios, la cesación requiere que la prestación y la concreción del resultado previsto se ejecuten y produzcan en un momento posterior al acto de constitución de la obligación.

En consecuencia, esta figura no es aplicable en los contratos de confección de obra material -y lo mismo cabe señalar de las prestaciones de servicios inmateriales- de ejecución instantánea y simultánea ${ }^{160}$.

b) Interés del artífice en el resultado

de la obra

Típicamente, el resultado material que se proyecta a partir del contrato -la obra confeccionada- tiene como único beneficiario al mandante. No obstante, en algunas situaciones las partes podrían compartir dicha finalidad, en cuyo caso este no estará facultado para cesar anticipadamente la obra. Puede ocurrir, por ejemplo, que el artífice necesite la obra para participar en un concurso arquitectónico, para darse a conocer en un mercado competitivo, etcétera.

Para que proceda esta limitación, sin embargo, se requiere de un acto de autonomía privada que la imponga al mandante. La regla de la cesación se encuentra establecida en su interés; en consecuencia, al no existir ra40 zones de orden público, nada le impide renunciar a ella ${ }^{161}$. Pero si la renuncia no se estipula en forma expresa o no fluye de la naturaleza del contrato, el mandante siempre podrá apartarse de la obra ex 1999 inc. 2 del $C C$.

c) Ejercicio abusivo de la cesación

Acá pueden incardinarse todos aquellos supuestos de abuso del Derecho y que contrarían la buena fe objetiva. Entre ellos se encuentran:

\section{i. Cesación abrupta}

Alguna doctrina extranjera entiende que la buena fe grava al mandante con la carga de dar un preaviso que permita al artífice acomodarse a la nueva situación jurídica provocada a partir de la cesación, aun cuando la ley no contemple expresamente esta modalidad ${ }^{162}$. La extensión del plazo dependerá de la naturaleza de las obligaciones contraídas y de las concretas circunstancias del caso.

\footnotetext{
${ }^{159}$ Véase supra IV.

${ }^{160}$ Así se ha sostenido, por ejemplo, en Francia. Véase Huet (1996), p. 1310.

${ }^{161}$ Gálvez (2008), p. 63.

${ }^{162}$ En el Derecho italiano, es la opinión de Iudica (2004), p. 248.
} 
Entendemos que el mismo planteamiento es aplicable para el art. 1999 inc. 2 del $C C$, considerando que su construcción es prácticamente la misma que en el resto de los ordenamientos donde se ha planteado la cuestión ${ }^{163}$.

Como sostiene Antonio Gálvez, se trata de una carga que no afecta la validez de la cesación, pero cuyo incumplimiento da lugar a la obligación de indemnizar los perjuicios causados ${ }^{164}$. Estos perjuicios son extrínsecos - por cuanto van más allá del valor de la prestación comprometida por el mandante ${ }^{165}$ - y se someten a las reglas generales del art. 1558 del $C C$ (id quod interest). Por lo tanto, deben ser previsibles y causalmente reconducibles a su incumplimiento ${ }^{166}$.

ii. Incumplimiento de la obligación de reembolso de los gastos y pago de la utilidad

Hemos dicho que, comunicada la cesación de la obra, se extinguen las obligaciones del artífice. También que el mandante, junto con reembolsar al artífice todos los costos en que incurrió antes de la fecha efectiva de la cesación ${ }^{167}$, debe pagar la utilidad estipulada.

Entendemos que el incumplimiento de estas obligaciones constituye una fuente potencial de daños cuya reparación puede ser demandada por el artífice, verificándose los demás presupuestos de causalidad y previsibilidad.

${ }^{163}$ Véanse supra n. 8.

${ }^{164}$ Gálvez (2008), p. 56.

${ }^{165}$ Corral (2010), p. 155.

${ }^{166}$ En todo caso, en uno de los pocos juicios resueltos conforme al art. 1999 del $C C$ inc. $2^{\circ}$ se negó la cobertura indemnizatoria amplia que proponemos en este trabajo.

En A-Lim S.A. con Administradora Golf Batuco S.A. (2009) el actor/artífice perseguía la indemnización del perjuicio extrínseco causado por la terminación intempestiva de un contrato de construcción de una cancha de golf, alegando que el mandante no cumplió su obligación de reembolsar los gastos y pagar la utilidad convenida. También adujo que no cumplió con sus deberes de colaboración y lo difamó ante la comunidad del club. Con todo, el tribunal se limitó a ordenar el reembolso y pago de las sumas estipuladas en el contrato, disponiendo el rechazo del perjuicio consecuencial por estimar que el art. 1999 inc. $2^{\circ}$ del $C C$ constituye una avaluación anticipada de perjuicios efectuada por el legislador. En los considerandos respectivos del fallo se lee: "Cuadragésimo cuarto: Que, por último, la actora solicita se condene a la demandada a pagar a la actora los perjuicios que le irrogó el incumplimiento doloso del contrato por parte de la demandada, cuya naturaleza y cuantía se reserva para la etapa de cumplimiento de la sentencia. Cuadragésimo quinto: Que la petición anterior deberá ser rechazada, por cuanto, como señala el artículo 1.999 del Código Civil, la demandada se encontraba facultada para hacer cesar el contrato, lo que excluye la posibilidad de que pueda estimarse dolosa la conducta de la demandada, y además, porque los perjuicios han sido avaluados por el legislador en forma anticipada, en la misma disposición citada”.

167 Véase supra III 3. b) i. 
iii. Los supuestos complejos de abuso del mandante

Finalmente, en este apartado podemos englobar todas aquellas situaciones de mayor envergadura en las cuales se produce un manifiesto abuso del Derecho que causa perjuicios para el artífice ${ }^{168}$. Un ejemplo lo constituye la interferencia en contrato ajeno. Puede suceder que un tercero, compitiendo deslealmente, induzca al mandante a provocar la terminación anticipada de la obra, privando al artífice de potenciales beneficios conectados con ella, como contratos de mantención de los trabajos ejecutados, etc. ${ }^{169}$. Al igual que en el supuesto anterior, el daño experimentado por este último, es indemnizable conforme a las reglas generales.

$\mathrm{Al}$ respecto, podría plantearse la discusión sobre el alcance del resarcimiento (art. 1558 inc. 1 del CC in fine). En concreto, la duda es si la mayor indemnización incluye las oportunidades perdidas, como originalmente lo concibió Robert Pothier. En principio, creemos que la cuestión debe responderse en forma negativa, puesto que esa indemnización no se fundará en un incumplimiento previo del mandante, sino en la contradicción de la cesación con la buena $\mathrm{fe}^{170}$. De este modo, obstaría a la reparación de dichos daños el necesario vínculo de causalidad.

\section{CONCLusiones}

1. La obligación de reembolso y pago de la utilidad que pesa sobre el mandante que provoca la cesación, no constituye una auténtica indemnización de perjuicios, sino la contraprestación contraída en el acto constitutivo de la relación contractual.

2. La cesación no implica una excepción al principio del efecto obligatorio de los contratos, si se le vincula con el deber de actuar de buena fe y satisfacer la expectativa contractual ajena. Porque, en definitiva, producida la terminación anticipada de la obra, el mandante cumplirá igualmente con la contraprestación proyectada al momento de la constitución del acuerdo contractual.

3. La cesación constituye un interesante dispositivo que permite componer su interés ante el acaecimiento de circunstancias sobrevenidas ubicadas dentro de su ámbito o esfera de control e influencia.

4. Considerando que los efectos de la cesación no dan origen a una indemnización de perjuicios tarifada por el legislador, el ejercicio

${ }^{168}$ Rodríguez-Palmero Seuma (2010), p. 27.

${ }^{169}$ Algunos casos similares han sido resueltos ante los tribunales europeos. Véase al respecto BANFI (2013), pp. 244-245.

${ }^{170}$ En este sentido, Rodríguez (1991), pp. 330-331 y Gálvez (2008), p. 62. 
contrario a la buena fe de aquella permite al artífice resarcirse de todos aquellos perjuicios consecuenciales al valor de la prestación (id quod interest), en la medida que se verifiquen los requisitos de previsibilidad y causalidad generales (art. 1558 del CC).

\section{Bibliografía CITADA}

Aguayo, Juan (2011). Las manifestaciones y garantías en el derecho de contratos español. Pamplona: Thomson Reuters.

Aguilera y Velasco, Alberto (1881). Código Civil italiano, comentado, concordado y comparado con las legislaciones vigentes en Europa y América. Madrid: Librería Universal de Córdoba y Compañía.

Albaladejo, Manuel (2002). Derecho Civil II, Derecho de obligaciones. Undécima edición. Barcelona: Librería Bosch, S.L.

Albiez Dohrmann, Klaus Jochen (2002). "Un nuevo derecho de obligaciones. La reforma 2002 del BGB”. Anuario de Derecho Civil. Tomo 55. № 3. Madrid.

Alcalde Silva, Jaime (2008). "El 'commodum repraesentationis' del artículo 1677 del 'Código Civil' de Chile”. Revista de Derecho de la Pontificia Universidad Católica de Valparaíso, vol. xxxi. Valparaío. $2^{\circ}$ semestre.

Alcalde Silva, Jaime (2011). "La responsabilidad contractual en el Código Civil: del particularismo al régimen general”, en Gonzalo Figueroa Yáñez, Enrique Barros Bourie y Mauricio TaPia Rodríguez (coords). Estudios de Derecho Civil VI. Santiago: LegalPublishing.

Alessandri Rodríguez, Arturo (1988a). Teoría general de las obligaciones. Santiago: Editorial Jurídica Ediar Conosur Ltda.

Alessandri Rodríguez, Arturo (1988b). De los contratos. Santiago: Editorial Jurídica Ediar Conosur Ltda.

Alonso Pérez, Mariano (1967). Sobre la esencia del contrato bilateral. Salamanca: Universidad de Salamanca.

BAdosa Coll, Ferrán (1987). La diligencia y la culpa del deudor en la obligación civil. Zaragoza: Publicaciones del Real Colegio de España.

Bahamondes, Claudia (2011). "Concurrencia de la indemnización de daños y la pretensión de cumplimiento específico frente al incumplimiento contractual", en Iñigo DE LA MAZA (coord.). Cuadernos de Análisis Jurídico: Incumplimiento contractual. Nuevas perspectivas. Santiago: Ediciones Universidad Diego Portales. Colección Derecho Privado, vol. viI.

BANFi del Río, Cristián (2013). Responsabilidad civil por competencia desleal. Estudio de derecho chileno y comparado. Santiago: Thomson Reuters.

BARAONA GonZÁlez, Jorge (1997). "Responsabilidad contractual y factores de imputación de daños: apuntes para una relectura en clave objetiva". Revista Chilena de Derecho. Vol. 24, Nº 1. Santiago. 
BaraOna González, Jorge (1998). El retraso en el cumplimiento de las obligaciones. Madrid: Dykinson.

Barassi, Lodovico (1955). Instituciones de derecho civil. (trad.) Ramón García de Haro de Goytisolo. Barcelona: José María Bosch Editor. Vol. II.

Barbero, Domenico (1967). Sistema del derecho privado. (trad.) Santiago Sentis Melendo. Buenos Aires: Ediciones Jurídicas Europa-América. Tomo IV.

Barcía Lehmann, Rodrigo (2007). Lecciones de derecho civil chileno. De las fuentes de las obligaciones. Santiago: Editorial Jurídica de Chile. Tomo III.

Barros Bourie, Enrique (2012). "Los contratos de servicios ante la doctrina general del contrato: La virtualidad de las reglas sobre el mandato", en Fabián Elorriaga de Bonis (coord). Estudios de Derecho Civil VII. Santiago: Thomson Reuters.

Baudry-Lacantinerie, G. (1925). Précis de Droit Civil. Paris: Librairie de la Société du Recueil Sirey. Tome deuxiéme.

Bello, Andrés (1888). Obras completas de don Andrés Bello. Santiago: Impreso por Pedro G. Ramírez. Vol. XII.

Beltrán de Heredia y Castaño, José (1956). El cumplimiento de las obligaciones. Madrid: Editorial Revista de Derecho Privado.

BetTi, Emilio (1969). Teoría General de las Obligaciones. (trad.) José Luis de los Mozos. Madrid: Editorial Revista de Derecho Privado. Tomo I.

Boetsch Gillet, Cristián (2011). La buena fe contractual. Santiago: Editorial Jurídica de Chile.

Borda, Guillermo (1997). Tratado de derecho civil, contratos II. Séptima edición actualizada. Buenos Aires: Editorial Perrot.

Branca, Giuseppe (1978). Instituciones de derecho privado. (trad.) Pablo Macedo. Ciudad de México: Editorial Porrúa S.A.

Brantt Zumarán, María Graciela y Mejías Alonzo, Claudia (2016). "El derecho supletorio del contrato de servicios en el Código Civil chileno. Insuficiencia de las reglas del mandato y del arrendamiento". Revista de Derecho de la Pontificia Universidad Católica de Valparaíso. Vol. XLVI. Valparaíso. $1^{\text {er }}$ Semestre.

Capitant, Henri (sin fecha). De la causa de las obligaciones. (trad.) Eugenio Tarragato y Contreras. Madrid: Góngora.

Carrasco Perera, Ángel (2010). Derecho de contratos. Cizur Menor: Thomson Reuters.

Castan Tobeñas, José (1988). Derecho civil español, común y foral. Décimo cuarta edición. Madrid: Reus.

Castilla Barea, Margarita (2000). La imposibilidad de cumplir los contratos. Madrid: Dykinson.

Colin, Ambrosio y Henri Capitant (1925). Curso elemental de derecho civil. Tomo cuarto. Tercera edición. Madrid: Editorial Reus.

ContARdo GonzÁlez, Juan Ignacio (2011). "Los criterios de interés contractual positivo y negativo en la indemnización de perjuicios derivada de resolución 
contractual". Revista de Derecho Universidad Católica del Norte. Año 18. № 1. Coquimbo

CONTARDO GONZÁLEZ, Juan Ignacio (2015). Indemnización y resolución por incumplimiento. Santiago: Thomson Reuters.

Corral Talciani, Hernán (2010). Contratos y daños por incumplimiento. Santiago: LegalPublishing.

Cristóbal Montes, Ángel (1989). El incumplimiento de las obligaciones. Madrid: Tecnos.

De Ángel Yagüez, Ricardo (1969). Los créditos derivados del contrato de obra. Madrid: Editorial Tecnos.

Del Olmo Guarido, Natalia (2004). El caso fortuito: su incidencia en la ejecución de las obligaciones. Pamplona: Aranzadi.

De la MaZA, Lorenzo (1950). Derecho civil. Contratos. Santiago: Editorial Universitaria.

De los Mozos, José Luis (1965). El principio de la buena fe. Barcelona: Bosch.

Díez-Picazo, Luis (2008). Fundamentos del derecho civil patrimonial. Madrid: Editorial Aranzadi. Vol. II: Las relaciones obligatorias.

Díez-Picazo Giménez, Gema (1996). La mora y la responsabilidad contractual. Madrid: Civitas.

D’Ors, Álvaro (1992). Elementos de derecho privado romano. Pamplona: Ediciones Universidad de Navarra.

Elizalde Ibarbia, Francisco de (2015). El contenido del contrato. Pamplona: Thomson Reuters.

Elorriaga de Bonis, Fabián (2002). "Ponencia principal presentada por el profesor don Fabián Elorriaga de Bonis [sobre la teoría de los riesgos]", en Fundación Fernando Fueyo Laneri, Estudios sobre reformas al Código Civil y Código de Comercio. Santiago: Editorial Jurídica de Chile. Segunda parte.

Enneccerus, Ludwig, Theodor Kipp y Martin WolfF (1966). Tratado de derecho civil. Derecho de obligaciones. (trad.) Blas Pérez González y José Alguer. Barcelona: Bosch, Casa Editorial. Vol. 2, primera parte.

Espert SAnz, Vicente (1968). La frustración del fin del contrato. Madrid: Editorial Tecnos.

FERnÁNDEZ UrZAinQui, Francisco Javier (1996). "La regla de la simultaneidad en el cumplimiento de las obligaciones bilaterales". Cuadernos de Derecho Judicial, $\mathrm{N}^{\circ} 8$ Madrid.

FisaC De Ron, María Paloma (2001). El cumplimiento del contrato de obra: la recepción. Madrid: Marcial Pons.

Fischer, Hans (1928). Los daños civiles y su reparación. (trad.) W. Roces. Madrid: Editorial Revista de Derecho Privado.

Flume, Werner (1998). El negocio jurídico. (trad.) José María Miquel González y Esther Gómez Calle. Madrid: Fundación Cultural del Notariado. 
Fuller, Lon L. y William R. Perdue (1957). Indemnización de los daños contractuales y protección de la confianza. (trad.) José Puig Brutau. Barcelona: Bosch, Casa Editorial.

Galgano, Francisco (1992). El negocio jurídico. (trad.) Francisco de P. Blasco Gascó y Lorenzo Prats Albentosa. Valencia: Tirant Lo Blanch.

Gálvez GarRido, Antonio (2008). La relevancia de la persona en los contratos de obra y servicios. Valencia: Tirant Lo Blanch.

García Caracuel, Manuel (2014). La alteración sobrevenida de las circunstancias contractuales. Madrid: Dykinson.

García del Corral, Ildefonso (1889). Cuerpo del Derecho Civil romano, a doble texto, traducido del castellano del latino. Primera parte, Instituta-Digesto. Barcelona: Jaime Molinas, Editor.

García Goyena, Florencio (1852). Concordancias, motivos y comentarios del Código Civil español. Madrid: Imprenta de la Sociedad Tipográfico-Editorial. Tomo III.

Gatica Pacheco, Sergio (1959). Aspectos de la indemnización de perjuicios por incumplimiento del contrato. Santiago: Editorial Jurídica de Chile.

Gaudemet, Eugéne (2010). Teoría general de las obligaciones. (trad.) Pablo Macedo. Ciudad de México: Editorial Porrúa.

Gavidia SÁnchez, Julio Vicente (1987). "Presuposición y riesgo contractual". Anuario de Derecho Civil, Madrid: abril-junio.

46 Gianfelici, Mario César (2004). La frustración del fin del contrato. Buenos Aires: Hammurabi.

Hedemann, Justus Wilhelm (1958). Tratado de derecho civil. (trad.) Jaime Santos Briz. Madrid: Editorial Revista de Derecho Privado. Vol. III: Derecho de obligaciones.

Hidalgo García, Santiago (2012). El contrato y los terceros. Pamplona: Thomson Reuters.

Holmes Jr., Oliver Wendell (1964). The Common Law. (trad.) Fernando N. Barrancos y Vedia. Buenos Aires: Tipográfica Editora Argentina.

Huc, Théophile (1897). Commentaire theorique \& practique. Paris: Librairie Cotillon. Tome $\mathrm{x}$.

Huet, Jérome (1996). Traité de droit civil. Les principaux contrats spéciaux. París: Librairie Générale de Droit et de Jurisprudence.

IUDICA, Giovanni (2004). "La buena fe en el cumplimiento del contrato de locación de obra o de servicios", en Marcos M. CóRdoba (director) y Lidia M. GARRIDO Cordobera y Viviana KLuger (coordinadoras). Tratado de la buena fe en el derecho. Buenos Aires: La Ley. Tomo II.

Jordano Fraga, Francisco (1987). La responsabilidad contractual. Madrid: Civitas.

Josserand, Louis (1951). Derecho Civil. Contratos. (trad.) Santiago Cunchillos y Manterola. Buenos Aires: Ediciones Jurídicas Europa-América. Tomo II. Vol. 2.

KLEIN, Michele (1997). El desistimiento unilateral del contrato. Madrid: Editorial Civitas. 
Lamarca Marquès, Albert (2001). El hecho del acreedor y la imposibilidad de la prestación. Zaragoza: Publicaciones del Real Colegio de España.

LamarCa MarquĖs, Albert (2013). Código Civil alemán y Ley de Introducción al Código Civil. Madrid: Marcial Pons.

Larenz, Karl (1956). Base del negocio jurídico y cumplimiento de los contratos. (trad.) Carlos Fernández Rodríguez. Madrid: Editorial Revista de Derecho Privado.

LarenZ, Karl (1958). Derecho de obligaciones. (trad.) Jaime Santos Briz. Madrid: Editorial Revista de Derecho Privado. Tomo I.

Larenz, Karl (1959). Derecho de obligaciones. (trad.) Jaime Santos Briz. Madrid: Editorial Revista de Derecho Privado. Tomo II.

Larenz, Karl (1966). Metodología de la ciencia del derecho. (trad.) Enrique Gimbernat Ordeig. Barcelona: Ediciones Ariel.

Lira Urquieta, Pedro (1956). El Código Civil chileno y su época. Santiago: Editorial Jurídica de Chile.

Llamas Pombo, Eugenio (1999). Cumplimiento por equivalente y resarcimiento del daño al acreedor. Entre la aestimatio rei y el id quod interest. Madrid: Editorial Trivium.

Loewenwarter, Víctor (1935). Derecho civil alemán. Santiago: Prensas de la Universidad de Chile. Tomo 1.

Macanás Vicente, Gabriel (2014). "La facultad de desistimiento en los contratos de servicios (cincumplimiento remediable o instrumento responsable?)", en Isabel González Pacanowska y Carmen Leonor García Pérez (coords.). Estudios sobre incumplimiento y resolución. Pamplona: Editorial Aranzadi.

López Díaz, Patricia Verónica (2015). La autonomía de la indemnización de daños por incumplimiento de un contrato bilateral en el Código Civil chileno. Santiago: Thomson Reuters.

Manresa y Navarro, José María (1908). Comentarios al Código Civil español. Madrid: Imprenta de la Revista de Legislación. Tomo X.

Martínez Velencoso, Luz María (2003). La alteración de las circunstancias contractuales. Madrid: Civitas.

Medicus, Dieter (1995). Tratado de las relaciones obligacionales. (trad.) Ángel Martínez Sarrión. Barcelona: Bosch, Casa Editorial. Vol. I.

Meza Barros, Ramón (2002). Manual de derecho civil. De las fuentes de las obligaciones. Reimpresión de la octava edición. Santiago: Editorial Jurídica de Chile. Tomo I.

Molina Morales, Ranfer (2014). "La retractación en los contratos", en Emilssen GonzÁlez de Cancino, Édgar Cortés Moncayo y Felipe Navia Arroyo (eds.). Estudios de derecho civil en memoria de Fernando Hinestrosa. Bogotá: Universidad Externado de Colombia. Tomo II: Contratos.

Morales Moreno, Antonio Manuel (2006). La modernización del derecho de obligaciones. Navarra: Editorial Aranzadi S.A.

Morales Moreno, Antonio Manuel (2010). Incumplimiento del contrato y lucro cesante. Madrid: Editorial Civitas. 
Morales Moreno, Antonio Manuel (2014a). "La noción unitaria de incumplimiento en la propuesta de modernización del Código Civil", en Isabel González Pacanowska y Carmen Leonor García Pérez (coords.). Estudios sobre incumplimiento y resolución. Pamplona: Editorial Aranzadi.

Morales Moreno, Antonio Manuel (2014b). "Claves de la modernización del derecho de contratos", en Íñigo DE la Maza Gazmuri, Antonio Manuel Morales Moreno y Álvaro Vidal Olivares. Estudios de derecho de contratos. Formación, cumplimiento e incumplimiento. Santiago: Thomson Reuters.

Mosset IturRaspe, Jorge y Miguel A. Piedecasas (2008). La revisión del contrato. Buenos Aires: Rubinzal-Culzoni Editores.

Navarro Albiña, René David (2005). Teoría general del contrato y contratos en particular. Santiago: Ediciones Jurídicas de Santiago.

Oertmann, Paul (1933). Introducción al derecho civil. (trad.) Luis Sancho Seral. Barcelona: Editorial Labor.

Ordoqui Castilla, Gustavo (2011). Buena fe en los contratos. Madrid: Editorial Reus.

Orrego Acuña, Juan Andrés (2011). El contrato de arrendamiento. Segunda edición actualizada. Santiago: Editorial Metropolitana.

Orozco Muñoz, Martín (2015). El enriquecimiento injustificado. Pamplona: Thomson Reuters.

Palazón Garrido, María Luisa (2014). Los remedios frente al incumplimiento en derecho comparado. Pamplona: Thomson Reuters Aranzadi.

Pantaleón Prieto, Fernando (1991). "El sistema de responsabilidad contractual (materiales para un debate)". Anuario de Derecho Civil. Vol. 44, No 3. Madrid.

Pantaleón Prieto, Fernando (1993). "Las nuevas bases de la responsabilidad contractual". Anuario de Derecho Civil. Tomo 46, No 4. Madrid.

Peñailillo Arévalo, Daniel (2009). "Responsabilidad contractual objetiva", en Carlos Pizarro Wilson (coord). Estudios de Derecho Civil IV. Santiago: LegalPublishing.

Pizarro Wilson, Carlos (2004). "La influencia del Code en el derecho de obligaciones. ¿Existe la responsabilidad contractual?”, en Ian HenríQuez HerRera y Hernán Corral Talciani (eds.). El Código Civil francés de 1804 y el Código Civil chileno de 1855. Influencias, confluencias y divergencias. Cuadernos de Extensión Jurídica. Santiago: Universidad de los Andes.

Pizarro Wilson, Carlos (2009). "La responsabilidad contractual en el derecho chileno", en Fabricio Mantilla Espinosa y Francisco Ternera Barrios (directores académicos). Los contratos en Derecho Privado, Bogotá: Legis Editores.

Pizarro Wilson, Carlos (2010). "Hacia un sistema de remedios al incumplimiento contractual”, en Carlos Pizarro Wilson y Álvaro Vidal Olivares. Incumplimiento contractual, resolución e indemnización de daños. Bogotá: Editorial Universidad del Rosario.

Planiol, Marcel y Georges Ripert (1991). Tratado elemental de derecho civil. (trad.) José M. Cajica. Tijuana: Cárdenas Editor y Distribuidor. Tomo v. 
Posner, Richard (2013). El análisis económico del derecho. (trad.) Eduardo L. Suárez. México, D.F.: Fondo de Cultura Económica.

Pothier, Robert (1764). Traité du contrat de Louage. Orleans: Imprimeur du Roi, de la Ville, \& de l'Université.

Pothier, Robert (1841). Tratado de la locación-conducción. Barcelona: Imprenta y Litografía de J. Roger.

Puig Brutau, José (1956). Fundamentos de derecho civil. Barcelona: Bosch, Casa Editorial. Tomo I. Vol. I.

Prat Echaurren, Jorge (1940). Nociones sobre el contrato de construcción privada. Santiago.

RaY, José Domingo (1996). Frustración del contrato. Buenos Aires: Abeledo-Perrot.

Rezzónico, Luis María (1959). Estudio de los contratos en nuestro derecho civil, Segunda edición. Buenos Aires: Depalma. Tomo II.

Ricci, Francisco (Sin fecha). Derecho civil teórico y práctico. (trad.) Eduardo Ovejero. Madrid: La España Moderna. Tomo XVII.

Ríos Erazo, Ignacio Javier y Rodrigo Pascual Silva GoÑI, (2014). Responsabilidad civil por pérdida de la oportunidad. Santiago: Editorial Jurídica de Chile.

Rodríguez Grez, Pablo (2008), Extinción no convencional de las obligaciones. Santiago: Editorial Jurídica de Chile. Vol. 2.

Rodríguez Marín, Concepción (1991). El desistimiento unilateral. Madrid: Editorial Montecorvo, S.A.

Rodríguez-Palmero Seuma, Pablo (2010). "El resarcimiento en caso de desistimiento del contrato de obra, ces realmente distinto del que derivaría del régimen general?)". Revista Chilena de Derecho y Ciencia Política. Año 1. Vol. 2. $\mathrm{N}^{\mathrm{o}}$ 1. Temuco

Ruggiero, Roberto de (1931). Instituciones de derecho civil. Traducción de la cuarta edición italiana. (trad.) Ramón Serrano Suñer y José Santa - Cruz Teijeiro. Madrid: Editorial Reus. Volumen segundo.

Saint Joseph, Antoine de (1852). Concordancia entre el Código Civil francés y los códigos civiles extranjeros. (trad.) F. Verlanga Huerta y J. Muñiz Miranda. Madrid: Centro de Suscripciones de la Ilustración, Semanario, Biblioteca y Novedades.

Salvador Coderch, Pablo (2006). "Artículo 79", en Luis Díez-Picazo y Ponce DE LEÓN (coord.). La compraventa internacional de mercaderías. Comentario de la Convención de Viena. Cizur Menor: Thomson Civitas.

Sánchez Calero, Francisco Javier (1978). El contrato de obra. Su cumplimiento. Madrid: Editorial Montecorvo.

Sánchez Calero, Francisco Javier (2004). Curso de derecho civil II. Derecho de obligaciones, contratos y responsabilidad por hechos ilícitos. Valencia: Tirant lo Blanch.

San Julián Puig, Verónica (1996). El objeto del contrato. Pamplona: Aranzadi.

SAn Martín Neira, Lilian (2015). "Algunas consideraciones sobre el contrato para la confección de obras material. Problemas derivados de su configura- 
ción típica”, en Álvaro Vidal Olivares, Gonzalo Severin Fuster y Claudia Mejías Alonzo (eds.). Estudios de Derecho Civil X. Santiago: Thomson Reuters.

San Miguel Pradera, Lis Paula (2004). Resolución del contrato por incumplimiento y modalidades de su ejercicio. Madrid: Colegio de Registradores de la Propiedad y Mercantiles de España.

Sentis Melendo, Santiago (1954). Código Civil italiano. Buenos Aires: Ediciones Jurídicas Europa-América.

Solé Resina, Judith (1996). Delimitación del objeto del contrato de arrendamiento de obras o servicios. Bellaterra: Universidad Autónoma de Barcelona.

Solé Resina, Judith (1997). Los contratos de servicios y de ejecución de obras. Madrid: Marcial Pons.

Terraza MartorelL, Juan (1951). Modificación y resolución de los contratos por excesiva onerosidad o imposibilidad en su ejecución. Barcelona: Bosch, Casa Editorial.

Urrejola Santa María, Sergio (2007). La responsabilidad profesional de los agentes de la construcción. Santiago: LexisNexis.

Vaquero Pinto, María José (2005). El arrendamiento de servicios. Propuesta de modelo general para la contratación de servicios. Granada: Editorial Comares.

Vidal Olivares, Álvaro (2006). La protección del comprador. Valparaíso: Ediciones Universitarias de Valparaíso.

VIDAL Olivares, Álvaro (2010). "El incumplimiento de obligaciones con objeto fungible y los remedios del acreedor afectado. Una relectura de las disposiciones del Código Civil sobre incumplimiento", en Carlos Pizarro WiLson y Álvaro Vidal Olivares. Incumplimiento contractual, resolución e indemnización de daños. Bogotá: Editorial Universidad del Rosario.

\section{Jurisprudencia citada}

Tupper y otro con Polla Chilena de Beneficencia (1962): Corte Suprema, 19 de diciembre de $1962, R$, tomo 59 , sec. $1^{\text {a }}$, p. 469.

A-Lim S.A. con Administradora Golf Batuco S.A. (2009): $28^{\circ}$ Juzgado Civil de Santiago, 25 de agosto de 2009 (indemnización de perjuicios), rol No 39545/2007.

Zorín S.A. con Compañía Siderúrgica Huachipato S.A. (2012): Corte Suprema, 31 de octubre de 2012 (casación en la forma y en el fondo), rol N ${ }^{\circ} 3325 / 2012$.

Club Hípico de Santiago con Koslan S.A. (2013): Corte de Apelaciones de Santiago, 25 de enero de 2013 (apelación), rol No 4363/2011.

Stange Hoffman Eduardo con Ripley Puerto Montt (2013): Corte Suprema, 2 de octubre de 2013 (casación en la forma), rol No 8607/2012.

Laboratorios de Control Técnico Llay Llay Ltda. con Celestron Ltda. (2014): Corte Suprema, 26 de noviembre de 2014 (casación en el fondo), rol No 14008/2013.

Corporación Nacional del Cobre de Chile, Codelco Chile, División Codelco Norte con Consorcio Constructora Araneda Brain Chile Ltda. (2015): Corte 
Suprema, 8 de octubre de 2015 (casación en la forma y en el fondo), rol $\mathrm{N}^{\circ}$ 32960/2014.

Román Canales con Televisión Nacional de Chile (2016): Corte de Apelaciones de Santiago, 17 de mayo de 2016 (casación en la forma), rol No 10.066/2015.

Packans Ltda. con Zhong Xiao Fan (2016): Corte Suprema, 25 de octubre de 2016 (casación en el fondo), rol No 81/2016. 